\title{
Trolldomssak mot en samisk noaide- Anders Poulsen, Vadsø, 1692
}

Av Liv Helene Willumsen

Professor i historie

UiT - Universitetet i Tromsø

E-mail: liv.willumsen@uit.no

$\underline{\text { www.livhelenewillumsen.no }}$

\section{Innledning}

Rettssaken mot Anders Poulsen i Vadsø, 1692, har i flere tiår fanget forskeres interesse. ${ }^{1}$

Dette skyldes flere forhold: For det første er saken interessant kronologisk som trolldomssak betraktet. Det er den siste sak under trolldomsprosessene i Finnmark der den anklagede mister sitt liv. For det andre er saken interessant fordi det i sakens løp ikke anføres at Poulsen hadde skadet noen ved sin trolldomsutøvelse. Anders Poulsen ble anklaget "formedelst hand haver hafft oc brugt it instrument Runnebomen Kaldet. Oc derved øvet dend Sleme U-gudelige Throlddoms Kunst". ${ }^{2}$ Anders Poulsen var en gammel noaide som eide og brukte runebomme, og denne ble konfiskert før rettssaken startet. Endelig dom i saken vites ikke, da det etter saken på bygdeting skulle innhentes avgjørelse fra København og Anders Poulsen ble holdt i rettslig forvaring i påvente av dette svaret. Imidlertid ble Poulsen drept med $\varnothing \mathrm{ks}$ av en mentalt ustabil person dagen etter at rettssaken mot ham i lokal rett var over. For det tredje er rettsreferatet fra denne saken intakt. Poulsens bekjennelse er nedskrevet i et referat på 16 sider, et meget fyldig dokument. Rettsreferatet i denne saken er dermed også interessant som historisk kilde betraktet, med et rikt tilfang av stoff. For det fjerde er saken interessant som dramatisk hendelse betraktet, da den har et anslag av sterk urett fra begynnelsen av og får det verst tenkelige tragiske utfall. Alle disse forhold underbygger at rettssaken mot Anders Poulsen har fanget interesse ut fra et historiefaglig perspektiv.

Imidlertid er saken mot Anders Poulsen også interessant ut fra et religionshistorisk perspektiv, og det er nødvendig i den sammenheng å klargjøre hvordan jeg forholder meg til to problemfelt; for det første problematikk knyttet til den delen av religiøs praksis som ofte omtales som sjamanisme, for det andre problematikk knyttet til overgangen fra eldre samisk religionsutøvelse til kristendom. 
I henhold til religionshistoriker James R. Lewis tolket Mircea Eliade i sin bok om sjamanisme fra 1951 sjamaisme som "a complex of particular ideas and practices that were widespread but not universal" ${ }^{3}$ mens senere forfattere som Carlos Castanda og Michael Harner bruker sjamanisme som en betegnelse for en viss form for religiøs praksis brukt $\mathrm{i}$ tradisjonelle samfunn over hele verden. ${ }^{4}$ Begrepet samisk sjamanisme vil ikke bli benyttet $\mathrm{i}$ denne artikkelen, da jeg anser det for å være et meget problematisk begrep. Det er vanskelig å hevde at en viss form for sjamanisme kan kalles samisk sjamanisme, noe som er et hovedsynspunkt i Håkan Rydvings religionshistoriske arbeider. ${ }^{5}$ Min oppfatning er at man kan snakke om paralelle former for religiøs praksis, men aktivert innenfor forskjellige sosiokulturelle rammer. ${ }^{6}$ I stedet for samiske sjamanisme vil her den nordsamiske termen noaidevuohta anvendes. Siden dette er et nordsamisk ord, er det unødvendig å sette inn det bestemmende ordet samisk først. Noaidevuohta er den aktuelle formen for religiøs praksis som omtales i artikkelen, der begrepet er å forstå som den delen av religiøs praksis i et samisk samfunn som innbefatter en noaides bruk av runebomme. Jeg vil heller ikke anvende ordet sjaman, men bruke noaide, som er den norske formen for det samiske ordet noaidi. Jeg forstår noaidevuohta som en del av et sett av religiøse praksiser utøvd i nordsamiske områder, og som kan la seg integrere i sammenheng med andre religiøse tradisjoner. Noaidevuohta er ikke i seg selv å forstå som en religion, og begrepet brukes i artikkelen ikke synonymt med termen førkristen samisk religion.

Det andre problemfeltet som berøres i analysen av det rettsdokumentet som tas opp til drøfting i artikkelen. er overgangen fra førkristen samisk religion til kristendom. Denne overgangen har trolig gått gjennom mange stadier, noe også Håkan Rydving påpeker i sin doktorgradsavhandling. Dette medfører at enkeltpersoners religiøse identitet ikke nødvendigvis forholder seg kun til én religiøs tradisjon, det kan kan være snakk om gradvise overganger før en person gir sin fulle tilslutning til en ny religion. I mange tilfeller kan dette ha influert opplevelse av egen religiøs identitet i et spenningsfelt mellom førkristen samisk religion og kristendom. Jeg har respekt for dette synspunktet, men min analyse av det konkrete rettsdokumentet fra saken mot Anders Poulsen fører i en annen retning. Jeg vil fremsette det synspunkt at Anders Poulsens utleggelse av runebommens symboler ikke framstår som et resultat av en overgangsfase når det gjelder religiøs innsikt og tilegnelse, men som en bevisst strategi i en faktisk gitt - og meget truende - rettslig kontekst.

Som enhver historisk kilde er en analyse av dette rettsdokumentet avhengig av fortolkning. Ikke minst er fortolkningen interessant når det gjelder spørsmålet hva dette 
dokumentet sier om førkristen samisk religion. Det er i 1993 blitt hevdet av Einar Niemi at rettsreferatet fra Anders Poulsens sak er "den mest omfattende førstehånds samtidskilde vi har om tradisjonell samisk religionsutøvelse, og især av bruken av trolltromme". 7 Niemi legger senere til at dette "er en av de viktigste kilder overhodet til vår kunnskap om samisk sjamanisme". ${ }^{8}$ Rune Blix Hagen refererer i flere artikler til Niemis uttalelser uten å ta avstand fra oppfatningen om at Anders Poulsens tilståelse gir kunnskap om genuin noaidevuohta og tradisjonell førkristen samisk religiøs praksis. Hagen hevder: "Som en studie i samisk sjamanisme kan vi lese tekstene fra Poulsen-saken som en slags innfallsport til 1700-tallets forestillinger om magi." ${ }^{9}$ Hagen hevder også, igjen med referanse til Einar Niemi, at saken mot Anders Poulsen er den beste kilde til kunnskap om noaidevuohta i nordlige del av Skandinavia. ${ }^{10}$ Også Hagens artikkel "Samer er trollmenn i norsk historie", som hovedsakelig handler om rettssaken mot Anders Poulsen, er fundert på det synet at utlegningen av runebommens symboler i denne saken er troverdig fordi det er trommens eier som kommer med utsagnene; det er snakk om "en av de ytterst få trommene der vi har eierens egen forklaring av trommens symboler og figurer". ${ }^{11}$ Niemi og Hagen fortolker rettsreferatet ut fra pålydende verdi, som et dokument som kan gi direkte innsyn i tradisjonell samisk førkristen religiøs praksis og noaidevuohta . Jeg ønsker i denne artikkelen å imøtegå påstandene om at rettsreferatet er en uovertruffen kilde til kunnskap om noaidevuohta og heller spørre om i hvor stor grad man kan feste lit til Anders Poulsens utlegninger. Hvorvidt står Poulsens forklaring av trommens symboler til troende? Det sikreste svaret finnes etter min mening i en analyse av hva Poulsen selv i sin tilståelse for retten uttaler. En slik analyse må innbefatte ikke bare selve rettsdokumentet, men også ta hensyn til konteksten, en rettssak der den anklagede er hardt presset.

Rettssaken mot Anders Poulsen er en trolldomssak. I de aller fleste trolldomssaker er mønsteret at den anklagede til slutt tilstår det som vedkommende tror forhørerne ønsker å høre; de tilstår det som blir forventet av dem. Noe slikt er trolig tilfelle i saken mot Anders Poulsen også. Mange av symbolene på runebommen forklares av Anders Poulsen ut fra kristendommen, noe som kan være et resultat av hva han tror forhørerne vil oppfatte som gunstig og dermed kan bidra til å påvirke utfallet av saken. Det som kommer fram under rettssaken er nødvendigvis ikke den kunnskapen om noaidevuohta som Poulsen selv sitter inne med, et synspunkt fremmet av Ernst Manker allerede i 1950: «Die auffallend christlichen Elemente in dieser Deutung von Poulsen weisen darauf hin, dass er die Figuren so christlich wie möglich erklären wollte, wobei er wahrscheinlich vieles über die ursprüngliche 
Bedeutung verschwieg.» ${ }^{12}$ Ut fra en slik fortolkning av Poulsens tilståelse forblir den genuine kunnskap om trommens symboler en hemmelighet, likeså Poulsens ytterligere kunnskap om førkristen samisk religionsutøvelse. Et av de spørsmål jeg i denne artikkelen ønsker å reise, er om Anders Poulsen i sin tilståelse under rettssaken virkelig avslørte sin kunnskap om førkristen samisk religiøs praksis og om trommens symboler? Jeg vil basere analysen på rettslokalets diskurs, et omfattende internasjonalt forskningsfelt som står i gjeld til den språklige vending fra 1990-tallet, et metodologisk veiskille som har hatt fundamental innvirkning på en lang rekke faglige disipliner. En slik metodisk tilnærming vil tjene til å motvirke en stivnet og gammeldags tekstlig innsikt og forståelse, der skriftlige dokumenter kun gjenfortelles og analyseres på et overflatenivå. I det følgende vil denne problematikken bli drøftet ut fra Anders Poulsens bekjennelse, rettsreferatets tilblivelse samt relativt samtidige kilder som omhandler noaidevuohta.

I et historiografisk lys er rettssaken mot Anders Poulsen meget omskrevet. ${ }^{13}$ Helt fra slutten av 1600-tallet foreligger tidlige norske omtaler av saken som har bidratt til å gjøre innholdet for forskere. ${ }^{14}$ Oppmerksomheten omkring trolldomssaken mot Anders Poulsen har ikke avtatt blant forskere de siste fem tiår. Jeg vil her fremheve nyskapende arbeider av Håkan Rydving 2010, 2007, 1993 og 1988. ${ }^{15}$ Dessuten er Anders Poulsen og saken mot ham kortfattet presentert av Einar Niemi. Artikler er skrevet av Rune Blix Hagen, Brita Pollan, Stein Roar Mathisen og meg selv. ${ }^{16}$ Hagens og Pollans artikler har et gjenfortellende preg både når det gjelder rettssakens gang og innholdet av Poulsens tilståelse. Mathisens artikkel har et annet fokus, den analyserer museumsutstillinger av samiske trommer. ${ }^{17}$

Fire vesentlige aspekter ved rettsreferatet fra saken mot Anders Poulsen vil bli tatt opp i det følgende. Jeg ønsker å drøfte rettssakens diskurs, Poulsens utlegning av runebommens symboler, rettsreferatet i kontekst samt kildens verdi som informasjon om noaidevuohta. Metodologisk er analysen av rettssakens diskurs basert på Gérard Genettes verker Narrative Discourse. An Essay in Method (1972), Narrative Discourse Revisited (1983) og Fiction and Diction (1991). Genette påpeker at det er mulig å lytte ut ulike diskursive "stemmer" i alle tekster med narrativ struktur, stemmer da forstått som en abstrahert størrelse. Han nevner "judicial narratives" som tekster der analyse av diskurs vil være fruktbar. Et rettsreferat betraktes i sin helhet som en fortelling, ført i pennen av en skriver, og narrative strukturer som konstituerende for tekstens oppbygning på ulike nivåer. I min analyse vil hovedvekten ligge på Anders Poulsens stemme og hva den formidler, men også lovens stemme og skriverens 
stemme vil bli berørt. ${ }^{18}$ En analyse av rettssakens diskurs vil innebære drøfting av hva de ulike stemmer utsier.

Det andre aspektet jeg ønsker å gå inn på, er knyttet til rettsreferatets utlegning av runebommens symboler. I størstedelen av rettsreferatet er det Anders Poulsens stemme vi hører, der han på spørsmål avgir en lang og detaljert bekjennelse. For utlegningen av runebommens symboler er denne stemmen bærende. Det er også dette punktet rettsmyndighetene i særlig grad ønsker belyst.

Det tredje aspektet er knyttet til kontekstuell forståelse av kilden: Hvordan kan Poulsens forklaring på runebommens symboler fortolkes når man ser hele dokumentet $\mathrm{i}$ den sammenheng det er blitt til i? Jeg vil argumentere for at i denne saken er en analyse av runebommens symbolikk absolutt beroende på at dokumentet forstås ut fra den rammen det er blitt til i, nemlig en rettssak. Et kjernespørsmål er hvordan Anders Poulsens bekjennelse kan fortolkes innholdsmessig, de gitte rammene tatt i betraktning.

Det fjerde aspektet ved rettsreferatet jeg ønsker å gå inn på, er hva dette dokumentet sier om noaidevuohta. Dette er et diskutabelt tema. Jeg ønsker jeg å belyse Poulsens forklaring i relasjon til noenlunde samtidig litteratur med informasjon om førkristen samisk religion og noaidevuohta. En slik gjennomgang vil sette Poulsens utlegning i relieff og rette søkelyset mot elementer man kunne forventet å finne i en forklaring av en erfaren noaide, men som uteblir.

\section{Rettssakens diskurs}

Analyse av rettslokalets diskurs er et omfattende forskningsområde. Ikke minst har skriverens rolle vært viet oppmerksomhet. Et viktig forskningsspørsmål har å gjøre med skriverens mulige innflytelse på det nedskrevne referatet. På dette punktet inntar forskerne ulike posisjoner. Noen påpeker at et historisk dokument forholder seg til en faktisk hendelse, eksempelvis Johan Tønnesson, som bruker betegnelsen 'faktuell prosa' ${ }^{19}$ Dette innebærer at skriveren besatt en høy grad av profesjonalitet og at man dermed kan feste lit til meningsinnholdet i det som står nedskrevet i et rettsreferat. Andre mener teksten kan sees som en tekstlig konstruksjon fra skriverens hånd, slik at det ikke blir mulig å forholde seg til en virkelig hendelse "bak" teksten. ${ }^{20}$ Selv er jeg av den oppfatning at skriveren var en profesjonell person som så det som sin målsetting å skrive ned så korrekt som mulig det som 
ble sagt og foregikk under rettssaken. Et slikt standpunkt er støttet av flere forskere. ${ }^{21}$ Særlig vil jeg understreke at muntlighetspreget i bekjennelsene støtter en slik forståelse. ${ }^{22}$

Bekjennelser og hele rettsreferater er skrevne tekster og krever fortolkning som skrift. Åpenbare kildekritiske spørsmål - som hvem er det som snakker, og hva er bekjennelsens intensjon og motivasjon innen en legal ramme - er avgjørende for analyse av rettsreferater. Rettsreferater befinner seg altså i en spesiell situasjon, mellom muntlig og skriftlig tekst, noe som er understreket av Elizabeth S. Cohen. ${ }^{23}$ Hver stemme framstår som distinkt. Cohens fortolkninger argumenterer for individualisering av et rettsdokuments stemmer, noe som attesteres av skandinaviske forskere, blant dem Jari Eilola, Marie Lennersand, Linda Oja, PerAnders Östling, Raisa Maria Toivo og meg selv. ${ }^{24}$

Når man skal analysere rettsreferatet fra saken mot Anders Poulsen, er det også spesielle forhold knyttet til skriverens rolle å tas i betraktning. Skriveren, sorenskriver Niels Knag, skrev ned referatet ut fra notater gjort under et forhør tidligere. Anders Poulsen ble fratatt sin runebomme den 7. desember 1691, og han ble forhørt dagen etter. Selve rettsmøtet fant sted 9. og 10. februar 1692. Forhøret fra desember 1691 ble referert til under rettssaken i februar 1692. Språksituasjonen var komplisert. Det var en tolk inne i bildet, som fortolket for rettsmyndighetene hva Anders Poulsen forklarte og for Anders Poulsen hva som ble sagt $\mathrm{i}$ rettssalen. Dette gjør at det er mange ledd den språklige utformingen av referatet. Når det gjelder formelle trekk, er språket tilpasset juridisk referats form. Imidlertid er det sannsynlig at meningsgehalten i Anders Poulsens bekjennelse er bevart i rettsreferatet. Skriveren har tilstrebet detaljert og nøyaktig protokollering, ikke minst har han forsøkt å fange muntlig tale og skriftfeste denne. ${ }^{25}$

\section{Anders Poulsens stemme}

Gjennom nærlesning av tekst - og da nærlesning forstått som metodisk grep - er det mulig å lytte ut ikke bare hva Anders Poulsen sa under rettssaken, men også hva han ble spurt om. Ved å avdekke såkalte skyggespørsmål kan man retrospektivt påvise hva det ble spurt om med utgangspunkt i hva som ble svart. Poulsen blir spurt om hva symbolene betyr, og svarer utførlig. Det er fem rader på runebommen, og på hver rad er der flere symboler. Et hovedspørsmål når det gjelder rettssakens innhold og dokumentets informasjon om noaidevuohta, blir: Hva er det Anders Poulsens stemme formidler om runebommens symboler? 
På den første rad er det tre symboler: figuren til et menneske, "som hand Kalder ilmaris, det er Storm oc Slem Veir", figuren til et menneske kalt Diermis, "det er torden", og "en Vild Reen $\beta$ lignel $\beta \mathrm{e}$, som hand Kalder Gvodde, det er en Vild Reen [Originalens kursivering]. ${ }^{26}$ Poulsen uttrykker at det er når Gud bedes om det, at virkning av skikkelsene oppnås.

Runebommen kan bli brukt i god og ond hensikt, men Guds navn ble kun nevnt i forbindelse med de gode virkningene. Om den første figuren, mennesket Ilmaris, heter det: "naar hand tilbeder gud; da skal den same indeholde oc til bage Kalde sit Sleme Veir, oc hand giør Vel slem Veir, men sider det er synd at bede derom". ${ }^{27} \mathrm{Om}$ den andre figuren, mennesket Diermis, heter det: "naar gud bedis, saa hielper diermis at naar det er flo Vejr med megit Regn, da kalder han det Vejr tilbage igien, oc at denne diermis hafuer ingen Magt før gud gif(uer) han(nem) forlof". ${ }^{28}$ Anders Poulsen tilstod også "at ilmaris Kand giøre unt oc slem Veir til at beskadige skiber oc baader, men diermis Kand giøre got Veir igien, oc forhindre det unde, naar hand faar lof dertil af gud". ${ }^{29}$ Om den tredje figuren, Gvodde, heter det: "Naar gud bedis, da gifuiß Ved dend løche til at faa skyde Vilde Reener, oc naar der spillis paa Runebomen, da der som Ringen iche Vil dandze til denne Reen, da faar hand som spørger effter god løche til Skøtterj, ingen Reen dengang, om hand endskiønt giør sin flid dereffter". ${ }^{30}$ Anders Poulsen gjentok hyppig ordene «Naar gud bedis». ${ }^{31}$ I referatet er "gud" konstant skrevet med liten forbokstav, kan hende fordi skriveren ville antyde at det ikke var den kristne gud som ble omtalt. 


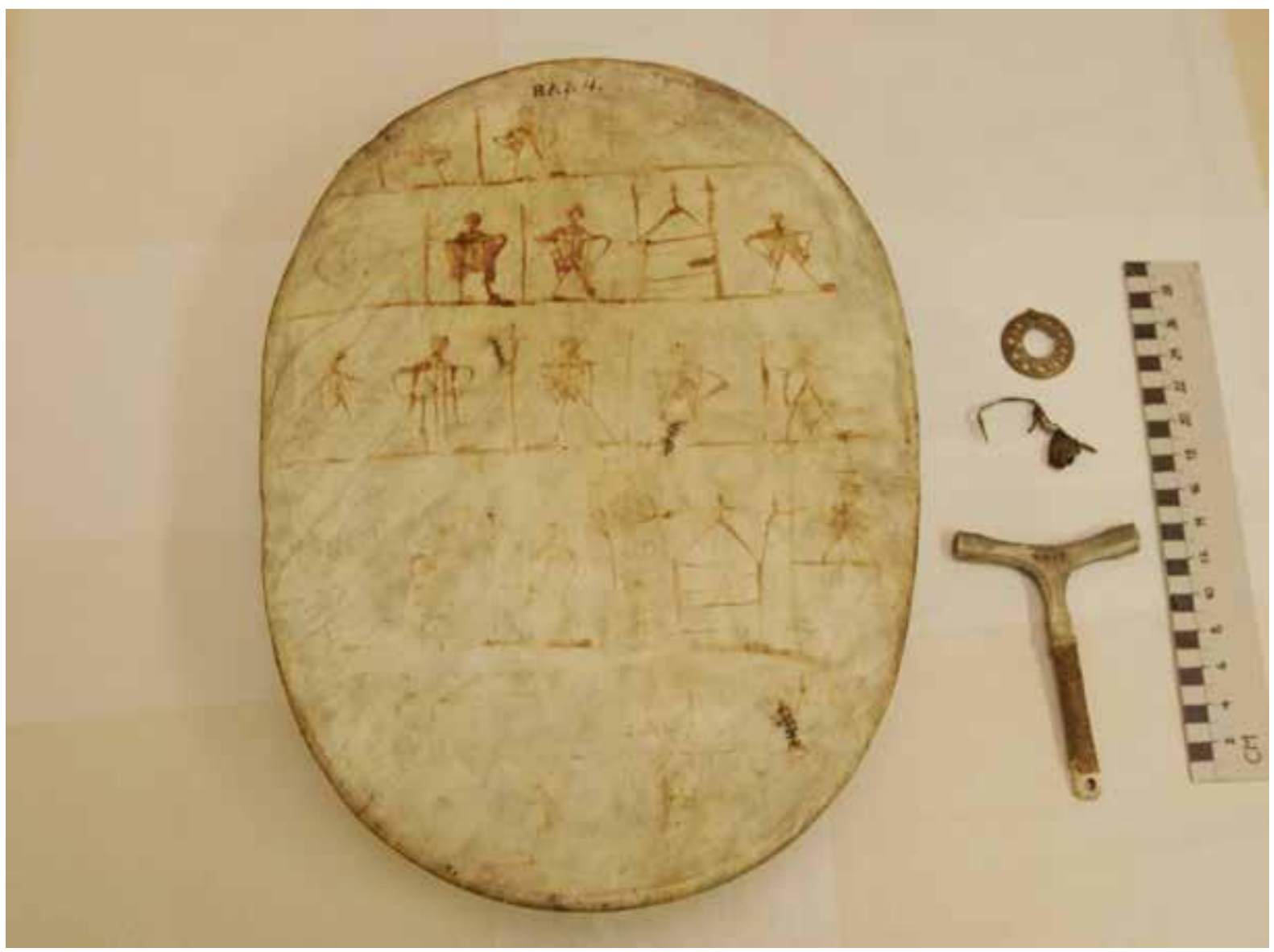

Figur 1. Anders Poulsens runebomme, De samiske samlinger, Karasjok.

Symbolene på første rad utlegges altså som to mennesker og et reinsdyr, og symbolene får virkning først når noaiden ber til Gud. Imidlertid understreker Poulsen Guds allmakt og den vanmakt symbolene i seg selv representerer. Gud er i posisjon til å delegere sin makt til sine hjelpere, som er representert på runebommen, men hjelperne kan handle kun på kommando fra Gud. Slik er med med Ilmaris’ evne til å lage dårlig vær for å skade skip og båter og Diermis’ evne til å gjøre været godt igjen, og forhindre det dårlige været; der er med Guds tillatelse dette skjer. Og selv om Ilmaris kan lage dårlig vær, sa Poulsen at det var synd å be om det. ${ }^{32}$ Dette antyder at det finnes en grense mellom bruk av runebommen i god eller dårlig hensikt, selv om begge deler er mulig. Slik er det også med figuren av det ville reinsdyret: den kan gi god eller dårlig lykke. Dersom ringen ikke vil danse for reinsdyret, vil jegeren ikke få noen rein, uansett hvor mye han prøver. Anders Poulsens forklaringer er ikke entydige. På den ene siden understreker han velsignelsene gitt av Gud gjennom figurene på runebommen, de positive virkningene av å praktisere trommingen. På den andre siden røper han at trommen også kan brukes i ond hensikt. Den Gud det er snakk om, er kristendommens Gud, dette gjentas mange ganger i Anders Poulsens forklaring. Symbolene avbildet på runebommen kan 
altså bli virkningsfulle gjennom kraft fra den kristne Gud, som Anders Poulsen bekjenner er den Gud han tilber og tror på. Poulsen omtaler Gud i entall, han nevner ikke guder i flertall. Symbolene Ilmaris og Diermis på første rad knyttes betydningen av godt vær, et generelt forhold. Mer spesifikt knyttes lignelsen Gvodde til samisk næringsvirksomhet og betydningen av god reinsdyrfangst, noe som betinger at kulturelle fortolkningsfaktorer aktiveres.

På den annen rad er det fem figurer. Den første er en rund sirkel med en strek gjennom, "dend Kalder hand peive, det er solen" [Originalens kursiv]. ${ }^{33}$ Når Gud bedes, "da skal dend gifue got Solskin, læt luft, oc smuch Veir, helst naar Reensdyrene Vil Kalfue, naar Korn oc høe skal Voxe, oc eller $\beta$ gifue got Veir naar derom bedi $\beta "{ }^{34}$ Den andre figuren er et menneskes lignelse "som hand Kalder Jumal barn, det er guds barn, eller gudz søn Christus, naar hand tilbedi $\beta$, saa løßer hand af alle Synder" [Originalens kursiv]. ${ }^{35}$ Den tredje figuren er et menneskes lignelse, "som hand kalder Jumal Etziem, det er Gud Fader, hand Straffer alle Synder, oc ellers hielper oc forskaffer, ia skicher, oc Straffer, naar hand derom bediß" [Originalens kursiv]. ${ }^{36}$ Den fjerde figuren er en kirke, "som hand kalder Dom Kirch, dend tilbeder hand effterdj hand dend self haf(ue)r giort". Han sier at ved den făr han "synderni $\beta$ forladel $\beta$ e, Siælen $\beta$ Salighed, oc en Christelig død, oc enten man døer eller lefuer saa hielper same Kirche". ${ }^{37}$ Den femte figuren er et menneskes lignelse, "som hand kalder Engil, det skal Vere gud dend hellig aand, naar hand bedi $\beta$, han løßer af alle Synder, saa mand blifuer et nyt ioc Reent Menniske naar hand Vil hielpe". ${ }^{38}$

På den annen rad utlegges de fem symbolene altså som en sol, Kristus, Gud Fader, en kirke samt Den Hellige Ånd. Den første figuren, Peive, solen, er litt forskjellig fra de andre i denne raden, da den er knyttet til velsignelsen av godt vær. Solen er et natursymbol og kan, på samme vis som figurene på første rad bidra til grødens vekst og gode forhold for reinsdyr som skal kalve. Tre av figurene på denne raden er religiøse symboler med kristen betydning. Den kristne hellige treenighet står sentralt i Poulsens utlegning: Guds sønn, Kristus, løser alle synder når han tilbes. Gud Fader er både straffende og hjelpende. Han straffer synder, men hjelper når han bes om det. Figuren Engil, utlagt som Den Hellige Ånd, tilgir alle synder når han bes om det, så man blir et nytt og rent menneske når han vil hjelpe. Den siste figuren på den annen rad er en domkirke, og Poulsen sier at han tilber den, ettersom han selv har laget den. Kirken skal gi syndenes forlatelse, sjelens salighet og en kristelig død. Totalt sett er symbolene på den annen rad sterkere enn symbolene på den første rad knyttet til en kristen dogmatikk, her er det man finner utlagt kristendommens kjernesymbolikk. Også for figurene 
på denne raden understrekes det at de er virksomme kun når Gud bes om det, og Anders Poulsen snakker om Gud i entallsform.

I tillegg knytter Anders Poulsen noen kommentarer til den Gud som er malt: "Dend gud som tilbedi $\beta$, som ofte meldet er, er de lignelßer oc figurer som hand af malet haf(ue)r effter personerne i Guddomen; som hand sige at hans Moder han(nem) lært hafuer". ${ }^{39}$ Første del av dette utsagnet fortolker jeg som opplysninger om de tre symbolene representative for den kristne treenighet, at figurene på runebommens andre rad viser til Faderen, Sønnen og Den Hellige Ånd i kristendommen. Imidlertid inneholder utsagnets siste del en oppsiktsvekkende opplysning, ettersom Poulsen sier at det er hans mor som har lært ham om personene i guddommen, underforstått den kristne lære. Det som ellers kommer fram i rettsreferatet om hans mors religiøse oppfatning, er at hun og en samisk mann i Torne Lappmark som skal ha lært Anders Poulsen sin kunst, "Var af en Thro", ${ }^{40}$ underforstått trodde moren på den førkristne samiske religion, og nettopp ikke har tatt ved kristendommen. Man ser her en tydelig motsigelse i det Poulsen uttrykker her og det han sier ellers i referatet; den grenseoppgang han ellers foretar, består i at han selv har tatt ved kristendommen, mens hans mor fremdeles er av den gamle tro. Når det gjelder spørsmålet om aktørene nevnt i rettssaken kan avspeile overgangsfaser mellom førkristen religion og kristendom, er min fortolkning ut fra ovenstårende at Anders Poulsen mente at hans mor og den samiske mannen i Torne Lappmark begge trodde på den førkristne samiske religion. Den språklige konteksten her tilsier at Poulsen mente de to var av samme tro, og denne troen var ikke kristendommen. Det er her ikke snakk om en blanding av førkristent og kristent. Avslutningsvis i forklaringen av symbolene på den annen rad, føyer Anders Poulsen til opplysninger om noen staver som er malt ved siden av personene på alle radene: "Ellers staar hos huer person i alle rader en Staf af Malet, som hand Kalder Juncher Sabbe eller Stur Herr Sabbe, det er Junchers Staf eller Store herrer $\beta$ Staf, tj hand siger lige som Jorden $\beta$ herrer, hafuer deri $\beta$ Staf $i$ haanden saa hafuer disße personer Stafuer i deri $\beta$ hender" [Originalens kursivering]. ${ }^{41}$ Det å ha en stav i sin hånd utlegges her som et attributt og et tegn på høy sosial status. Juncher - som egentlig har betydningen en ung adelsmann - var en tittel brukt om øverste embetsmann på Vardøhus og en tittel Poulsen trolig forbandt med den høyeste autoritet under kongen. I Anders Poulsens fortolkning var figurene på runebommen å ligne med jordiske adelsmenn eller embetsmenn. Det vi ser er en kobling mellom religiøs og verdslig autoritet ved at betydningen av disse stavene kobles til de ovennevnte symbolene malt på runebommen. 


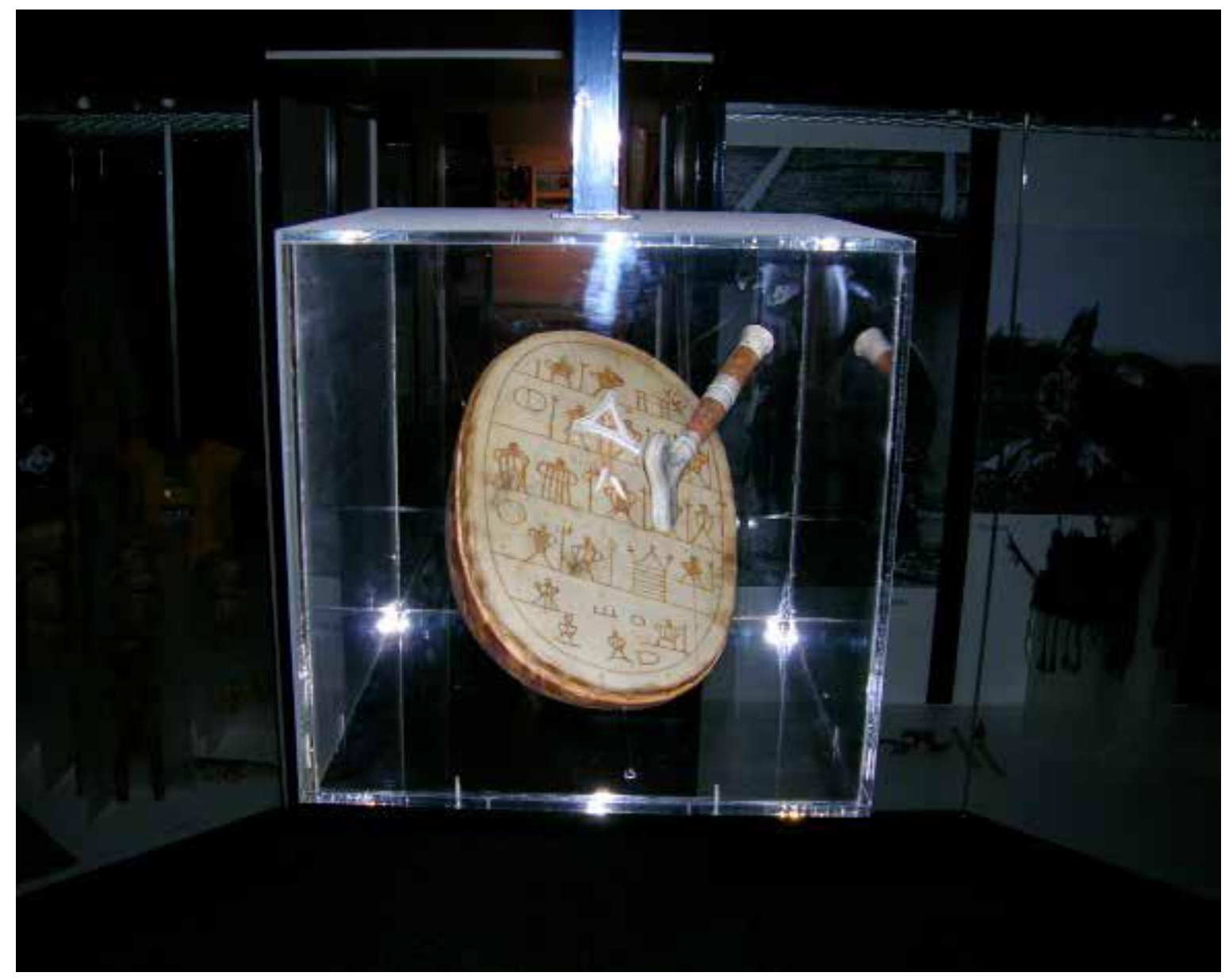

Figur 2. Kopi av Anders Poulsens runebomme. Redskapene er ikke kopi av de originale.

På den tredje raden er det fem skikkelser: For første gang blir noen av figurene på runebommen utlagt som kvinner. Først et menneskes lignelse, en kvinneskikkelse "som hand kalder $S^{t e}:$ Anna, oc sier hand at denne er Maries Søster, oc er i Raad // med Marie naar hun hielper, eller $\beta$ kand denne intet giøre uden Maries Villie". ${ }^{42}$ Ut fra Bibelen er St. Anne mor til Maria, her utlegges hun som Marias søster, så dette er en endring i forhold til den kristne lære. Den andre figuren på tredje rad er også en kvinneskikkelse "som hand Kalder oc Nefner paa adskillig maade, Maria, Jumal Enne, Jumal Ache, det er, Maria, Christi Moder, Gudz quinde, naar hun tilbedi $\beta$, hielper hun særdeli $\beta$ bar $\beta$ el quinder, hun hielper oc til at løße fra alle Synder, oc hielper oc tilbedi $\beta$ lige Ved gud". 43 Fortolkningen av Maria som Kristus' mor er i henhold til Bibelen, men utlegning av Maria som Guds kvinne er ikke i samsvar med protestantisk lære. Også at Maria kan løse fra alle synder, samt at hun tilbedes "lige Ved gud", gir henne en svært betydningsfull plass blant symbolene på runebommen. Det synes klart at funksjonen til de kvinnelige skikkelsene som er avbildet, er å hjelpe, da spesielt kvinner som føder eller som er i nød. 
I tillegg til de to kvinneskikkelsene er det på den tredje rad " 3 de: Menniskerß lignelse, som hand Kalder Julle peive, Julle herr, det er Jule dage, Julle herrer som Raader Julen, oucht Jule Peiv herr første Julle dags herre, Gougt Jule peive herr, Anden Julle dags herre, Gvolme Jul peive herr, tredie Julle dags herre". ${ }^{44}$ Et vesentlig moment er å helligholde disse dagene: "Naar nogen Vahn helliger disse dage, da skal gud Straffe dend, men naar nogen holder dem ret hellig, oc dend same Vil bede gud om noget, da stilles de dage frem for gud, oc foregifuis at dend eller dend hafuer holt de dage hellige, oc at Gud af dessen aarsage Vil hielpe". 45 Anders Poulsen ville ikke bekjenne mer om disse dagene, så her er det tydelig at han har fått flere oppfølgende spørsmål, men har ikke villet si mer. Utlegningen er klart knyttet til julen som kristen høytid med dager som ut fra det tredje bud skal holdes hellige. Gud framstilles slik at han velsigner dem som holder hans helligdager og straffer dem som ikke gjør det. Dette samsvarer med bildet av en straffende og hjelpende Gud Fader som ble utlagt på den annen rad.

På fjerde rad er det malt fem skikkelser: en rund sirkel som representerer månen, skikkelsene av to menn som går til kirke, avbildningen av den kirken Anders Poulsen tilhører samt skikkelsen til en mann som kommer til kirke fra den motsatte retningen. Når det gjelder symbolet for månen, Manna, forklarte Poulsen at "naar gud tilbedis, da giffuer den Klart skin oc got nat Veir, om end det er tycht skyed Veier". ${ }^{46}$ Så er det innført i referatet: "Videre Ville hand iche bekiende", noe som betyr at han er blitt spurt om å utdype dette med virkningen av månesymbolet, men ikke ønsket å si noe mer. Andre og tredje symbol på denne rad "Er 2de Mends Lignelße, som hand Kalder Olmoug Mane Kirche [originalens kursiv], det er folch som gaar til Kirche, huilche hand holder ichun for en bemerchning, lige som andre folch gaar til Kirche". ${ }^{47}$ De to menn som er avbildet gående til kirken, utlegges som helt vanlige kirkegjengere. Så følger et bilde av en kirke

oc skal betyde dend Kirche huor hand haf(ue)r sit tilhold Ved; til denne Kirche siger hand baade sig self oc andre offrer, baade Voxlyß penge oc andet, dog offrer ingen med mindre de blif(ue)r hiulpen, huilchet offer, de siden lefuerer til Presten til dend Rette Kirche, som denne afmalede haf(ue)r sin bemerchning af, item naar nogen er Syg, eller haf(ue)r Modgang paa Reen eller andet ont er nogen Vederfaret, da bediß oc lofuiß til denne Kirche, oc naar saa nogen blif(ue)r hiulpen da faar Kirchen huiß lofuet er, ${ }^{48}$

Dette symbolet utlegges som den kirke han hører til, og der han ofrer vokslys, penger eller annet. Imidlertid befordrer offeret, som gis til presten, en gjenytelse. Når det er snakk om sykdom eller motgang knyttet til rein, så blir det bedt til kirken, og når bønnen oppfylles, får 
kirken det som er blitt lovet. Offeret blir en garanti for at bønnen blir oppfylt. Det siste symbolet på denne raden er "En Mandz lignelße som Staar paa dend anden side Kirchen, det skal Vere en som Komer paa dend anden side oc Vil gaa til Kirche". ${ }^{49}$ De fire siste symbolene på fjerde rad knytter seg altså til kirkebygningen og kirkegang, og ofring til kirken skjer på betingelse av bønnhørelse.

På den femte og siste raden er det syv figurer - tre av disse er djevler og en er en djevels kvinne. I tillegg er det tre symboler som ikke er i menneskeskikkelse, men som er knyttet til helvete. Den første figuren er et "quindfolchß lignelße, som skal Vere dend bunden diefuel sin quinde, huis Nafn hand siger sig iche Vide". ${ }^{50}$ Den andre figuren utlegges som "Et Menniskes lignelße som Staar lidet wdenfor denne første, som hand siger skal Vere en diefuel som dræber folch, oc Mennisker, oc skal Vere Siugdom". 51 Den tredje figuren utlegges som "et Menniskeß lignelße lige for denne som melt er, som hand siger skal Vere dend diefuel som nu er $1 \varnothing e ß$ oc Regierer i helfuede oc Svefuer om i Verden, huilchen hand siger sig iche hafue nafn paa". ${ }^{2}$ Denne djevelen rømte da Gud bandt den djevelen som er omtalt nedenfor, en djevel i lenke. Det fjerde, femte og sjette symbolet er tegnet i referatet, slik:

4: Staar Saaledis $L \downarrow J$ dette Kalder hand Hilvet Tol, det skal Vere helvedis Jld, dend Jld brender Menniskenes Siæle i helfuede,

5: Staar Saaledis 8 . dette Kalder hand Hilved Tarve Giedme, som skal Vere helfuedis tiere Kiedel, som Kaager Mennisken $\beta$ siæle i helfuede,

6: Staar Saaledis $\longrightarrow$, dette Kalder hand Hilvet Haufd, det er helvedi $\beta$ graf, hour udj Kasti $\beta$ alle de Mennisker som tror paa diefuelen, oc Kaster Gud dem derudj [originalens kursiv $]^{53}$

Den siste figuren på femte rad er en bundet djevel, "Et Menniskes lignelse som haver en Streg lige fra halßen til en Støtte, denne Kalder hand Hvenaales Gvolisis, det er en bunden diefuel i lenche, som skal Vere dend diefuel som blef bunden da gud skabte Verden". ${ }^{54}$ Det hadde seg nemlig slik at "da gud fant denne, da hafde gud Jern skoe paa oc trøde denne i en Stor Myr". ${ }^{55}$ Utlegningen av de ulike djevlene og av helvete er farget av Bibelen og tanker om straff etter døden. I Poulsens forklaring er det menneskenes sjeler som oppslukes av flammene i helvete, ikke kroppene deres. Sjelene kokes i en tjærekjel, og det finnes en grav der for dem som tror på djevelen. Framstillingen avviker fra vanlige bilder av det kokende vannet i helvete. Det er snakk om flere djevler. En av dem er sykdom, én er en løs djevel og én er bundet. Under utlegningen om djevlene berøres Guds skapelse av verden og straffen som venter i helvete for dem som tror på Den Onde. Det er på femte rad djevlene er symbolisert, et skremmende 
område. Farligheten befinner seg nederst på runebommen. Den framstillingen Anders Poulsen gir, er meget jordnær med henblikk på billedbruk og forklaringsfaktorer. Det kom i denne runden ingen kommentarer fra rettens embetsmenn med hensyn til Poulsens fortolkning av symbolene, ingen oppfølgende spørsmål ble stilt.

Etter utlegningen av symbolene fortsatte Anders Poulsen med å forklare hvordan han brukte runebommen for å få svar på det han ville vite. Han hadde to hamre [må forstås som to gjenstander ut fra konteksten], gjort av reinhorn. Den ene kalte han som hand Kalder Qiaarve vetzier, "med dend ene bancher hand Jidelig paa Runnebomen naar hand noget Vil forrette". ${ }^{56}$ Den andre var en innhul messing dechel med en messingring oventil, som hand Kalder palm, denne setter hand paa Runnebomen". ${ }^{57}$ Poulsen viste for retten hvordan dette foregikk, "oc løfte Runnebomen op oc ned med sin haand, Vrier oc holder dend af oc til, oc imedens bancher med hameren, oc siger hand at Ved Mesßing dechelen faar hand at Vide om det eller det er sant eller ei". ${ }^{58}$ Det hadde betydning hvilken vei dechelen danset, om det var med eller mot solen. Motsatt, dersom den danset med solen, "da hafuer dend en goed løche hand spiller for". ${ }^{59}$ Dersom den danset mot solen, ville personen han spilte for ikke ha lykken med seg. Hvis den kom så langt ned at den stoppet ved en av figurene under den siste streken på femte rad, var Gud sint på den han spilte for. Den personen måtte be mye til Gud før ringen beveget seg tilbake igjen. Slik lot Gud vedkommende se at han var et syndig menneske. ${ }^{60}$

Så tok Anders Poulsen opp runebommen og demonstrerte hvorledes han spilte. Han korset først seg selv, så runebommen, og leste Fadervår på karelsk. ${ }^{61}$ Videre leste han bønnen ”ætziem, achie, ja barne, ja Engilen, væche don, med flere ord; oc skulle det vere Gud Fader, din Moder, ia din søn, ia dend hellig aand hielp nu". ${ }^{62}$ Han så på sine figurer,

oc dechelen dandzede op oc ned, oc hand banchet med hameren, oc foreholt guderne disße ord, ia du gud som har skabt himel oc Jord, Soel oc Maane, ia Stierner, alle Mennisker, ia fugle, ia alle fiske oc hafuet, oc bekiendte sine Synder sigende, ieg er et Syndig Menniske, gamel oc u-Verdig, bettre er det ieg døer, end du iche Vil hielpe den Vj spør eftter, derhoß siger sig at giøre løfte iche at Vil synde mere, med flere hanß tilbedende ord, ${ }^{63}$

I sitatet ovenfor brukes for første gang flertallsformen av ordet gud, samtidig med at entallsformen benyttes. Den praktiske demonstrasjonen av runebommen opp for en utvidet forståelse av hva som ligger i ordet gud. At Poulsen innbefatter en flertallsform, guderne, viser at hans forståelse av gudsbegrepet ikke er så entydig som han har forsøkt å vise tidligere i sin forklaring. Selv om han har vært bevisst på å tilstrebe en framstilling av den ene kristne Gud, vakler hans forklaring her og røper at han henvender seg til flere guder når han spiller på runebommen. Selve demonstrasjonen av spillingen bringer Poulsen nærmere den situasjon 
han konkret har vært i flerfoldige ganger under sin noaidevirksomhet, og da slår hans gamle oppfatning gjennom.

Anders Poulsen ble etterpå spurt om han kunne løfte gand. Han svarte at når det er satt gand i noen, "Kand hand Ved sine guder tage same gand ud oc lade dend Kome i dend same som haver dend først udsat". ${ }^{64}$ Igjen nevner Anders Poulsen guder i flertall, det er mer enn én gud som er virksom når han tar ut gand. Og han viste hvordan han løftet gand og spilte på runebommen til ringen kom ned på en av figurene på femte rad, som var en av djevlene. Da vek ganden fra den som hadde den og gikk over i den som hadde satt den ut. Han sa at han slik hadde hjulpet mange i "Sverig lapmarch", men ingen i Norge. På samme måten viste han hvordan ringen danset til en av djevlene dersom en tyv skulle straffes. Da spilte han så lenge "at gud Straffer tiufuen som noget har staalet, saa at hand tørchis oc Matris op at hand blif(uer) lige som tørt træ". ${ }^{65}$ Denne delen av Anders Poulsens bekjennelse har å gjøre med noaidens evne til å bruke runebommen for å finne svar på konkrete spørsmål. Men når det eksempelvis var snakk om å finne en tyv, gjenvisning, understreket han at det var Gud som straffet. Han sa også at ved bønn til Gud når han spilte på runebommen, kunne han skaffe reinsdyrene lykke, slik at ulver ikke skulle drepe dem, og også i andre henseende god lykke. Også når han hjalp barselkvinner, spilte han på runebommen og fikk vite Guds vilje når dechelen danset. ${ }^{66}$ Anders Poulsen understreket at han bare gjorde godt når han spilte på runebommen, og han sa at Kristus hadde forbudt både ham og hans sønn å gjøre noe vondt. Han hevdet at han kunne få svar fra runebommen når han holdt den høyt opp i luften, akkurat som når to mennesker taler med hverandre. ${ }^{67}$

Anders Poulsens fryktet for hva som kommer til å skje videre under rettssaken. Den klareste indikasjon på dette viser seg helt på slutten av hans bekjennelse. Han erklærte da at av alle de gjerninger han sa at han kunne forrette, "Ville hand ej tilstaa nogen af den(nem) her $\mathrm{i}$ landet at hafue øfuet eller brugt, oc der hoe $\beta$ protesterede paa sin $\mathrm{u}$-skyldighed oc at intet ont hafue forrettet" [originalens utheving]. ${ }^{68}$ Han sa også at han ikke hadde forsvoret Gud eller sin kristne tro, og når han tilbad de avmalte guder på trommen, mente han med dem Gud i himmelen. Og “efterdj hand fornehmer at det er øvrigheden imod at hand bruger Runnebomen, Vil hand dend nu forlade, oc lige som andre folch tro paa gud i himelen". [Min kursivering. $]^{69}$ Den siste setningen torpederer mye av det han har sagt under forhørets utlegning av enkeltsymboler. Kommentaren mer enn antyder at til tross for hyppige forsikringer om tro på den ene kristne Gud, var hans egentlige tro fremdeles den gamle samiske religion. 
Den neste dagen, som var 10. februar 1692, ble Anders Poulsen igjen kalt for retten, og på spørsmål svarte han at

da hand lærde Runnebomens Kunst af sin Moder skeede det af Aarsage, hand Ville Vide huor folch lef(ue)r langt fra, om de hafuer goed løche, hand derom spørger effter, om Reißendiß folch skal hafue goed løche, at Ville hielpe folch naar de Var i nøed, oc Ved same Kunst Ville giøre got, huilchet hanß Moder sagde at Slig Kunst skulle hun lære han(nem), men hand self iche begierede at Ville lære, ydermere blef hand om adskilligt tilspurt huor Ved hand alt tilstod dend forige bekiendelße, oc dend iche udj noget forandrede, ei heller Ville Videre om sit Væßen bekiende end det at Vere en Kunst oc spil huor Ved hand intet unt haf(ue)r forretted ${ }^{70}$

Poulsen stadfestet altså at han hadde lært runebommens kunst fra sin mor og at han ikke hadde gjort noe vondt med sin kunst og bare ønsket å hjelpe mennesker i nød. Kjennelsen innbefattet en gjennomgang av hovedelementene i Poulsens forklaring. Hans virksomhet omtales som " hanß Store U-gudelighed oc diefle Kunst" ${ }^{71}$ og det stadfestes at han hadde lært av sin mor "om hinde hand siger ei hafde dend rette tro til gud i himelen som andre folch, huilchet hand oc bekiender om sin ene søn Ved Nafn Christopher" ${ }^{72}$ og at hans sønn kan tale "Ved Steene" og få svar akkurat som han selv av runebommen. Det understrekes også "at hanß Søn Var Vild oc gal da hand lærde, huilchet alt er af høi forargelße, helst paa disße Vit afliggende Steder, huor en Stor deel Mennisker gandske lidet er opliust om dend rette Guds Kundskab oc d $\phi$ rchelß $e^{\prime \prime}$ [Min kursivering]. ${ }^{73}$ At Finnmark er et avsidesliggende sted betinger ut fra denne argumentasjon innbyggernes mangel på opplysning om den rette tro og gudsdyrkelse. Her ligger også en grunn til at folk henvender seg i feil og syndig retning: "naar den(nem) noget hender oc Veder faris, langt heller spørger Raad hos Saadanne Throldfolch, end indfly til gud med bøn oc paa Kaldelße". ${ }^{74}$ Imidlertid er dette en vanskelig sak å dømme i, og endelig avgjørelse kan ikke tas i Vadsø,

tj Var det høit fornøden, at der ofuer Slig U-gudelighed blef Statuerit et afskyelig Exempel, paa det guds Rette paa Kaldelse Kunde fremmiß; Da som deslige gierninger oc afgudsdørchelßse som Anders Pouelßen fri Villigen beKiender at hafue øfuet, oc er forfaren udj, ei udj lougen findiß benefnde, at de derefter Kunde af straffis, (huor om dog ingen Klager at hand nogen hafuer beskadiget paa lif, hilßen eller godzis Mistelse) haver hans Velbr: ambtmanden resolverit oc for Raadsom erachtet, effter at ieg med hans Velbr: derom hafuer Consulerit, at denne sag som er en U-sædvanlig Casus huorudj behøfuis dend høi øfrigheds betenchende oc skiøn, opsettis indtil høi øfrigheds Svar fra Kiøbenhafn indhentis, huorledis dermed skal forholdiß, oc acten imidlertid beskrefuen nedskichis [Originalens kursivering] ${ }^{75}$ 
Retten skulle avvente svar fra København, og i mellomtiden skulle Anders Poulsen holdes i rettslig forvaring i Vadsø. En oversikt over Anders Poulsens og hans hustrus middel og formue ble bekjentgjort i retten. Til sammen hadde hans bo en verdi på 32 våger og 12 mark. $^{76}$

Så holdes det et rettsmøte igjen i Vadsø den 22. februar. Det dreier seg om et mord. Anders Poulsen var blitt drept med øks dagen etter at hans rettssak var over. Morderen var en mentalt ubalansert person, Villum Gundersen fra Jølster, som arbeidet som dreng hos amtmannen. Han ble ført for retten og "sagde sig dertil ei at hafue anden aarsage end hand meente same find Var en trold mand oc Vel burde døe, end siger hand sig meente de Vare UVenner". ${ }^{77}$ Drapet hadde altså sin årsak i at Villum Gundersen mente Anders Poulsen var en trollmann, og ikke i at han mente Anders Poulsen med sin kristeliggjorte fortolkning av runebommen hadde forrådt den samiske tro. Poulsens arvinger krever et liv for et liv, men saken ender med at drapsmannen ikke dømmes til døden, ”at Villum gunderßen som haver Værit betaget sin sunde fornuft da hand dette drab øvede, bør ei derfore paa sit lif at Straffis, men af sin formue som hand haver, eller Kand hereffter bekomme, give fuld Mande boed". ${ }^{78}$

\section{Innhold og kontekst}

Å fortolke Anders Poulsens utlegning av symbolene på runebommen uten å ta i betraktning den kontekst utlegningen skjedde i, er etter min mening umulig. Alt som ble uttrykt av Anders Poulsen ble sagt under en rettssak der han var anklaget for trolldom og kunne forvente en alvorlig dom. Denne saken ble ført på slutten av 1600-tallet, etter et hundreårs alvorlig trolldomsforfølgelse i Finnmark med høy frekvens av dødsdommer. Enhver ny trolldomsanklage bar uvegerlig bud om et alvorlig utfall. Innenfor denne rammen er det Anders Poulsens bekjennelse må forstås.

Det er gjennom Anders Poulsens stemme, slik den er skrevet ned i rettsreferatet, at utlegningen av runebommens symboler presenteres. Fire av symbolene utlegges av Poulsen som natursymboler, nemlig sol, måne, storm og torden. Dessuten er det en figur som utlegges som en villrein. For samtlige av de andre symbolene, som utgjør størstedelen av trommens bilder, er det den kristne Gud og kristendommen som er referert til. Kristendommen gjennomsyrer Anders Poulsens utlegning. Runebommens språk som et religiøst språk synes å ha vært fleksibelt, ettersom nytt innhold og nye tilnærminger muliggjorde nye fortolkninger av runebommens strukturer og figurer. ${ }^{79}$ 
Anders Poulsens forklaring er ikke entydig. Dette gjelder flere aspekter, blant annet intensjonen for bruk av runebommen. På den ene siden understreker han velsignelsene gitt av Gud gjennom figurene på runebommen, de positive virkningene av å praktisere trommingen. Gjentatte ganger understreker han at han bruker trommen kun i god hensikt. Dette kan jo sees i sammenheng med at ingen hadde klaget på at Anders Poulsen hadde gjort noen som helst skade - et argument for at han snakker sant. På den andre siden røper han at trommen også kan brukes i ond hensikt, særlig hvis dechelen stopper ved en av figurene på femte rad og djevlene aktiveres.

Også når det gjelder hvem som var hans læremester, kommer en inkonsekvens til syne. Han vakler mellom moren og en samisk mann som læremester. Det ble spurt om hva slags gud han tilbad. Han svarte at den guden han tilbad, var de lignelser og figurer han hadde malt etter personene i guddommen "som han siger at hans Moder han(nem) lært hafuer". ${ }^{80}$ Hans mor hadde altså lært ham runebommens symboler. Samtidig sier han at moren ikke delte den kristne tro. Dermed må man anta at moren hadde lært ham betydningen av runebommens symboler i henhold til samisk religion, mens han i retten utlegger samme symboler knyttet til kristendommen. Uklarheter fortolkningsmessig kommer også til syne når Anders Poulsen utlegger betydningen av noen personer avbildet med staver på trommen. I Poulsens fortolkning kan disse sammenlignes med jordiske adelsmenn eller embetsmenn.

Påliteligheten i Anders Poulsens bekjennelse kan utfordres. Størstedelen av referatet fra hans sak er en fortellende tekst gjengitt $\mathrm{i}$ indirekte tale, en fortelling der han gir opplysninger om sitt liv og om runebommen. Opplysningene av biografisk art er antakelig korrekte, men det samme er neppe tilfelle med fortolkningen av symbolene på runebommen som del av en samisk noaides virke. Riktignok er hans demonstrasjon av spilling på runebomme, overbevisende. Dette var en mann med lang erfaring i slik bruk, og en som viste følelser: Med tårer strømmende nedover kinnene løftet han runebommen opp i luften og spilte på den, slik at alle de som var til stede i retten, kunne se det. ${ }^{81}$ I tillegg fortalte han trolig korrekt om de anledningene runebommen ble brukt. Imidlertid er bekjennelsen problematisk som kilde til kunnskap omnoaidevuohta. ${ }^{82}$ Den kan være korrekt når det gjelder de elementene av bekjennelsen som har å gjøre med natursymboler og næringsveier: solen, månen, storm, torden og ville reinsdyr. Imidlertid er det et spørsmål om hvorvidt Anders Poulsens bekjennelse som helhet står til troende når det gjelder tradisjonell bruk av runebommen. Anders Poulsen prøvde å tilpasse innholdet av sin bekjennelse til den protestantiske kirkes doktrine, en doktrine han ikke i detalj hadde kjennskap til. På den ene 
siden fors $\varnothing \mathrm{kte}$ han ved repetisjon av standard religiøse fraser å overbevise retten om at den ene Gud han tilba, var den kristne Gud. På den andre siden var hans bekjennelse inkonsistent og upålitelig på grunn av plutselige snu-manøvre mellom å proklamere tro på én Gud til å proklamere tro på mange guder. Særlig hans siste bemerkning om at fra nå av ville han kun tro på den rette, kristne Gud, antyder at han hadde tilhørt den førkristne samiske religion hele livet, som hans mor før ham.

Anders Poulsens fortolkning av runebommens symboler varierer med henblikk på troverdighet, og det er nødvendig å se nærmere på hvordan han beskriver de ulike figurene for å evaluere hans fortolkning. Hele tiden understreket han at når man ba til Gud, hjalp ham dem som spurte om hjelp. Han erklærte igjen og igjen at han brukte runebommen i god hensikt. Imidlertid var situasjonen for Anders Poulsen da han ble utspurt i retten, at han måtte overbevise retten om sin kristne tro. Natursymboler var lette å fortolke innenfor en ramme han kjente fra sitt daglige liv. Figurene som betegnet treenigheten var også mulig for ham å forklare ut fra den kristne kirkes lære. Det samme var runebommens evne til å forårsake ondt ved å bruke bildet av Gud som en straffende og velsignende Gud. Situasjonen var tilsvarende for figurene som betegnet kirker og folk som søkte til kirkene. Imidlertid var forhørerne mer interessert i de onde virkningene av runebommen, enn de gode. Problemene startet for alvor da Poulsen kom til den femte rad og bildene av djevlene dukket opp og måtte fortolkes. Han forklarte at dersom dechelen stoppet her, betydde det at personen det ble spilt for, var en syndefull person og derfor ville få sin straff. Myndighetene så dette som djevletilbedelse, selv om symbolene som betegnet helvete ble beskrevet med ord brukt i kristen forkynnelse. Min oppfatning er at de ulike elementene i Anders Poulsens bekjennelse bør differensieres. Noen utlegninger forklarer trommens potensial til å gi svar på spørsmål knyttet til blant annet værforhold og reinsdyrdrift. Disse er helt klart pålitelige ut fra trommens gamle bruk. Andre fortolkninger er knyttet til den protestantiske kristne religion og forklarer symbolene innenfor denne forståelsesrammen. Dette gjelder figurer som betegner treenigheten, kristne merkedager og straff for synd. Disse er problematiske ut fra trommens bruk knyttet til noaidevuohta.

Dersom man undersøker Anders Poulsens beskrivelser av symbolene på runebommen ut fra et slikt perspektiv, blir det klart at bekjennelsen er tvetydig, og at den bærer preg av ulike fortolkningsstrategier. Siden det kan stilles spørsmålstegn ved påliteligheten i Anders Poulsens bekjennelse, gir hans beskrivelse neppe et fullstendig bilde av den kunnskap og innsikt en erfaren noaide satt inne med. 
Årsaken til dette er den spesielle rammen rundt hans bekjennelse. Anders Poulsen ble forhørt av lovens embetsmenn i en kriminalsak. Utfallet av saken er ukjent, men negativt belagt. Men han kunne ha grunn til frykt. Han gjorde han sitt beste for å overbevise embetsmennene om at han adlød de ti bud, gikk til gudstjeneste i kirken og kun brukte trommen i det godes hensikt. Hans situasjon var vanskelig, ettersom han åpenbart hadde levd et liv i konflikt mellom sin egen samiske bakgrunn og den norske kulturen. Stemmen vi hører i Anders Poulsens bekjennelse er ikke konsistent. Han vakler mellom forskjellige "sannheter", for eksempel hvem som hadde laget runebommen, og hvem som hadde lært ham kunsten. Han er uklar når det gjelder bruken av runebommen, insisterer på de positive effektene av trommingen når man ber Gud om noe, men er unnvikende når det gjelder spørsmålet om hvem som er hjelper når trommen blir anvendt i vond hensikt. Utlegningen av symbolene på runebommen ville sannsynligvis blitt annerledes dersom rammen ikke hadde vært en rettssak.

\section{Lovens stemme}

Lovens stemme kommer tydeligst fram i begynnelsen og på slutten av referatet, mens hele midtpartiet er Anders Poulsens beretning, nesten en livshistorie. Runebommen ble lagt fram på tingbordet. Underfogden $\emptyset$ nsket at den bekjennelsen Anders Poulsen allerede hadde avlagt i nærvær av ham selv, viselagmann og "Finne lensmanden”, skulle bli lest opp og bekreftet. Underfogden formodet at ut fra denne bekjennelsen ville Anders Poulsens trolldomskunst og misbruk av Guds hellige navn fornemmes, noe han mente ikke burde foregå ustraffet. ${ }^{83}$ Lovens stemme, slik den høres gjennom underfogd Olle Andersens utsagn, røper at underfogden selv betraktet Anders Poulsens bruk av runebommen som ugudelig og straffbar. Dersom Anders Poulsen holdt fast ved sin tidligere bekjennelse, "formodede" underfogden at dette bekreftet Poulsens utøvelse av trolldom og hans misbruk av Guds navn. Den samme underfogden "formeente" at denne utøvelsen ikke kunne foregå ustraffet. Vi ser at bruken av verb røper Olle Andersens holdning til utøvelse av samisk magi og bruk av runebomme. Tidlig i saken mot Anders Poulsen er ord som "djevelsk" og "ugudelig” brukt i forbindelse med hans mor, som han hadde lært fra, og som ikke hadde den rette tro til Gud i himmelen. ${ }^{84}$ Denne måten å ordlegge seg på blir sterkere mot slutten av rettssaken, da kjennelsen skal avsies.

Runebommen ble igjen nevnt av lovens representanter som en introduksjon til Poulsens detaljerte beskrivelse av den. Tidligere hadde han bekjent at trommen som ble presentert i retten, var laget av ham. Nå benektet han dette, “det hand nu benechter”, og han sa 
at den var slitt av idelig bruk. ${ }^{85}$ Poulsen hadde altså under forhøret den 8 . desember vedgått at det var han som hadde laget runebommen, men under rettsmøtet 9. februar trakk han dette tilbake. Retten syntes likevel å tro at det var han som hadde laget runebommen og at benektelsen ble gjort for å mildne forbrytelsen han var anklaget for. Imidlertid snudde Poulsen igjen 9. februar og innrømmet at det var han som hadde laget runebommen, som vi kan se ut fra bruken av ordet "nu” i det følgende sitatet:"Udj dend første Rad staar, effter at hand $n u$ bekiente self af haffue giort Runnebomen" [Min utheving]. ${ }^{86}$

Lovens stemme kan høres ved enkelte ord eller uttrykk lagt inn i referatet. For eksempel er det i beskrivelsen av figuren Engel, som befinner seg på den andre rad, lagt til en formulering som skaper distanse til det Poulsen har fortalt: "Et menniskes lignelse som hand kaller Engil, det skal Vere gud den hellig Aand". ${ }^{87}$ Når det i referatet står "det skal Vere", innebærer dette trolig at skriveren stiller seg tvilende til det som Poulsen forklarer. Det samme uttrykket er brukt om utlegningen av en figur på fjerde rad, en rund sirkel, som han kalte Manna: "Det skal Vere Maanen". ${ }^{88}$ En sirkel kunne åpenbart ha andre fortolkningsmuligheter, så den distanserende formuleringen er på sin plass.

Spor av spørsmålene stilt under forhøret kan registreres gjennom hele bekjennelsen. Disse gir ekko av lovens stemme, om enn indirekte. Da Anders Poulsen hadde gitt sin beskrivelse av de tre figurene på tredje rad, som representerte juledagene, ble han åpenbart spurt om han hadde noe å tilføye, men "Videre Ville hand iche om de dage bekiende". ${ }^{89} \mathrm{Vi}$ finner det samme etter beskrivelsen av månen på fjerde rad: "Videre Ville hand iche bekiende" ${ }^{90}$ Det siste spor av spørsmål ser vi i den delen av bekjennelsen som handler om å løfte gand: "Paa til spфrgelse sagde han at naar nogen er sat gand udj Kand han Ved sine guder tage same gand ud" [Min utheving]. ${ }^{91}$ Spørsmålene som har vært stilt, antyder at rettens embetsmenn gjerne ville vite så mye som mulig om symbolene på runebommen. I rettslokalet spurte de derfor Anders Poulsen om å utdype sin tidligere bekjennelse. Særlig var de interessert i å vite om samisk trolldomskunst, for eksempel hvordan man tok bort gand som var kastet over en person. Men de var også interessert i å vite om de mørkere sider ved runebommens kunst, for eksempel hva som skjedde når runebommen ikke ga svar som innebar lykke og hell, noe Poulsen var motvillig til å gi, "men for ingen deel Ville sige at faa gudernis Svar anderledis end naar dechelen dandzer Ret om med Solen". ${ }^{92}$ Rettens menn var oppriktig interessert i å høre Anders Poulsens stemme, heller det enn å vise fram egen veltalenhet. På den måten demonstrerer de en mer åpen, lyttende og deltakende holdning til 
den anklagede personen enn det som kan spores i rettsreferatene fra trolldomssaker tidligere på 1600-tallet.

Mot slutten av saken blir det klart hva forhørerne har vært ute etter hele tiden mens de har lyttet til Anders Poulsen. Enkelte elementer i bekjennelsen ble understreket, særlig at hans kunst var av en djevelsk sort: "huorledis hans paa raabende Figurers lignelser paa Runnebomen, hannem Ved Fandens indskydelser indbilder de gierninger oc tegn han spørger oc søger efter, som efter hans tale hender oc Vederfares". ${ }^{93}$ Figurene på femte rad er beskrevet slik:"Udj dend 5te: Rad hafuer hand adskillige diefle med dend Elste diefuels quinde, oc helfuedis formeenende instrumenter afmalet, oc i Sær en diefuel som skal Vere siugdom, huilchen hand siger Kand dræbe oc døde Mennisker, af huilche figurer oc lignelser" [Originalens kursiv]. ${ }^{94}$ Retten fant hans verk å være meget straffverdig, særlig fordi han malte den hellige treenighets personer, Gud fader, Sønnen og den Hellige Ånd, som han ved sine besverginger og misbruk "som Gud for hannem skal forrette oc Kundgiøre, saa megit grovelig Van ærer, for achter, bespotter oc høit fortørner". 95 Også grunnlag for straff var lesning av Fader Vår i forbindelse med spilling på runebommen, og det at han tegnet hellige korsets tegn over seg og over runebommen før han begynte å spille. Det samme gjaldt at han satte sine bilder i Guds sted, som Guds skapte elementer, og at han sa til dem, "du Gud som skabte himel oc Jord, Sol oc Maane etc: oc endelig Ved det hand afmaler helfuede oc dieflene, huorom hand intet særdeles vil bekiende huorledes hand med dem omgaais".96

Retten vektla Anders Poulsens motvilje mot å gi detaljer om figurene på runebommen som representerte djevelen. Figurene ble ansett å representere hans gudløse og djevelske kunst, som han hadde lært fra sin mor. Det ble etablert et skille mellom samer som bekjente seg til den kristne tro, og de som ikke gjorde det. Anders Poulsen selv understreket at han bekjente seg til kristendommen. Hans sønn Christopher, som påstod at han hadde samtaler med Kristus gjennom å snakke med steiner, er også nevnt som trolldomskyndig. Retten fant at Anders Poulsens kunst var "af høi forargelse, helst paa disse Vit afliggende Steder, huor en Stor deel Mennisker gandske lidet er opliust om dend rette Guds Kundskab oc dørchelse af huilche en deel naar den(nem) noget hender oc Veder faris, langt heller spørger Raad hos saadanne Troldfolch, end indfly til gud med bøn oc paa Kaldelse" [Min utheving]. ${ }^{97}$ For første gang under rettssaken er ordet "Troldfolch" brukt, og det er stadfestet at det er nødvendig "at det ofuer slig U-gudelighed blef Statuerit et afskyelig Exempel, paa det Guds rette paa Kaldelse Kunde fremmis" [Originalens kursiv]. ${ }^{98}$ Imidlertid, siden slike gjerninger og avgudsdyrkelse som Anders Poulsen bekjente å ha utøvd, ikke finnes nevnt i loven, slik at de 
kunne straffe deretter, så bestemte amtmannen etter at "ieg med hans Velbr: derom haffuer Consulerit" [først min kursiv, så originalens kursiv] ${ }^{99}$ at dette var et uvanlig kasus som behøvde den høyeste $\emptyset$ vrighets betenkning og skjønn, og saken ble utsatt inntil den høyeste $\emptyset$ vrighets svar fra København var innhentet. ${ }^{100}$

\section{Skriverens stemme}

Stort sett er skriverens stemme nøytral og nedtonet, med ett unntak: Som nevnt i sitatet ovenfor, opptrer skriveren Niels Knag i første person som et 'ieg' - noe som forekommer svært sjeldent i denne typen dokument - når det gjelder konsultering med "Hans Velbårenhet" om hvordan denne spesielle saken skal håndteres. Det er ingen indikasjon i referatet på at skriveren er uenig i vurderingen av Poulsens bruk av runebomme som avgudsdyrkelse.

En måte skriveren skaper distanse til den historien Anders Poulsen fortalte, er ved å gi en beskrivelse av ham mens hans spilte på trommen. Poulsen så på sine bilder, og “dechelen dandzede op oc ned, oc hand banchet med hameren, oc foreholdt guderne disse ord (...)". ${ }^{101}$ Synet av en noaide i arbeid har en kort stund distrahert skriveren fra kun å referere hva som ble sagt. Han gir i stedet et glimt av situasjonen i rettslokalet, som må ha vært forbløffende, sett gjennom hans $\varnothing y n e$.

\section{Hva sier dokumentet om noaidevuohta?}

Hva utsier rettsreferatet fra saken mot Anders Poulsens om noaidevuohta? Tar man utgangspunkt i Anders Poulsen egen stemme og hans utsagn under rettssaken, mangler de vesentligste elementer som kunne fortelle oss hva en noaides virksomhet består i. I Poulsens utleggelse av runebommens symboler er ingen mannlige guddommer nevnt, ingen kvinnelige guddommer nevnt, ingen offerplasser nevnt. Dette til tross for at den samiske religion hadde et stort antall guder av begge kjønn og et stort antall offerplasser. Anders Poulsen sier at hans sønn taler "med sten", noe som trolig impliserer offerplasser, men at han selv ikke gjør dette. Når disse tre meget viktige elementer i den førkristne samiske religion er utelatt, er det vesentlige mangler ved kilden som informasjon om noaidevuohta.

Ut fra andre kilder har man en del kunnskap om noaidevuohta. Flere omfattende bibliografier over samisk religionshistorisk litteratur og samisk litteratur er gitt ut, der noaiden og hans virksomhet er viet betydelig plass, likeledes mannlige og kvinnelige guder i den samiske religion, eksempelvis studier av Håkan Rydving, J. Qvigstad og K. B. Wicklund samt Hans Mebius. ${ }^{102}$ 
Samtidig som saken mot Anders Poulsen fant sted i Vads $\varnothing$, ble saken mot samiske Lars Nilsson fra Piteå Lappmark holdt i Arjeplog i Sverige. ${ }^{103}$ En annen sak fra de finske samiske områder var saken mot Aikie Aikiesson fra Kittka i Kemi Lappmark i 1671, som ble anklaget for å bruke runebomme og å joike. ${ }^{104}$ Opplysninger om andre runebommer som er bevart, er gitt blant annet av Rendick Andersen fra Foldalen, som i 1723 beskrev en runebomme for Thomas von Westen. ${ }^{105}$ I tillegg finnes det en del beskrivelser av runebommer av senere dato, blant annet i boken Nåidkonst. Trolltrummans bildvärld av Ernst Manker. ${ }^{106}$

Det kjennskap man har til "norske lappers hedenskap" rundt år 1700, stammer hovedsakelig fra flere Relasjoner. ${ }^{107}$ I tillegg kan nevnes en del opplysninger i Major Peter Schnitlers Grenseeksaminajsonsprotokoller 1712-1745. ${ }^{108}$ Samiske guddommer som ikke finnes omtalt i Poulsens utleggelser, er omskrevet i ulike sammenhenger i løpet av de første tiårene etter 1700. En rekke mannlige samiske guddommer er omtalt av Jens Kildal i $1730 \mathrm{i}$ artikkelen "Afguderiets dempelse og den sande lærdoms fremgang". ${ }^{109}$ Hellige fjell omtales i Thomas von Westens brev til presteskapet i Jämtland, 1723. ${ }^{110}$ Samiske offerplasser er ellers utførlig omtalt i Ørnulf Vorren og Hans Kristian Eriksens bok Samiske offerplasser $i$ Varanger. $^{111}$

Noen av symbolene på Anders Poulsens runebomme kan knyttes til naturguder. Flere av disse er beskrevet i Rolf Kjellström og Håkan Rydving, Den samiska trumman (1988), og i prosten Henric Forbus' skrivelse, 1727. ${ }^{112}$ Også symbolene som utlegges av Poulsen som Juledags herrer, er omtalt i annen litteratur, blant annet er slike herrer vist til i Isaac Olsens relasjon "Om Lappernis Vildfarelser og Overtro" og Wiklund, Samerna i 1600-talets Sverige. Disse symbolene skal være knyttet til gamle merkedager. ${ }^{113}$

Det er avbildning av to kvinneskikkelser på Anders Poulsens runebomme. Her hadde man forventet at navnene på noen av de kjente samiske kvinnelige guder kom opp, gudinner som er svært vanlig å finne på runebommer, nemlig Sarakka, Uksakka og Juksakka. ${ }^{114}$ Men i stedet får vi Anna og Maria, i en utlegning ikke overensstemmende med kristen lære.

Når det gjelder hvorvidt trommespill var sentrum i saken mot Anders Poulsen, kan svaret være både ja og nei. Det var snakk om at en gammel samisk noaide ble fengslet for å ha brukt et instrument kalt en runebomme. Om dette instrumentets symboler og utforming ble han forhørt i retten. Når det gjaldt selve trommespillingen, hvordan han utførte det å spille på runebomme, så demonstrerte han dette i retten: løftet runebommen opp og viste hvordan han spilte. Men det gjenstår et viktig spørsmål, nemlig om det Anders Poulsen viste fram i retten, 
var en del av samisk religionsutøvelse som noaidevuohta. Min oppfatning er at hva Anders Poulsen viste fram i rettslokalet av trommespill ikke var en genuin demonstrasjon av hvordan en samisk noaide arbeider. Til det er rammene som en rettssal betegner og de naturlige rammene for Poulsens utøvelse av sin kunst innen en religiøs sammenheng alt for forskjellige. Der den naturlige intensjonen for en noaides arbeid er å være til hjelp for mennesker som trenger hjelp, var intensjonen i dette tilfelle en framsyning som skulle være svar på forhørernes spørsmål. Dersom man tar bort den intensjonelle delen av en noaides virke, tar man samtidig bort det alvor og de forpliktelser en noaide vanligvis jobbet $\mathrm{i}$ forhold til. At Poulsen i rettssalen kunne løfte opp runebommen og vise hvordan trommen brukes, sier lite om noaidevuohta som en kunst og en ferdighet og en innsikt. De religiøse overtoner er borte.

\section{Konklusjon}

Jeg har i artikkelen drøftet språklige, innholdsmessige, kontekstuelle og religiøse aspekter ved rettsreferatet fra saken mot Anders Poulsen. Det er ikke mulig å hevde med belegg i rettsreferatet at dette gir en autentisk beskrivelse av noaidevuohta eller av førkristen samisk naturreligion. Imidlertid synes runebommens språk som et religiøst språk å ha vært fleksibelt; nye fortolkninger av runebommens faste strukturer og figurer var mulig. ${ }^{115}$

Den billedbruk og retorikk Poulsen bruker, viser til den kristne treenighet og avspeiler sentrale tanker i den kristne lære: Gud som en sterk, velsignende og straffende far, Kristus som tilgir alle synder og Den Hellige Ånd, som gjør det mulig å bli et nytt og rent menneske. ${ }^{116}$ Utlegningen av Den Hellige Ånd ligner mye på forklaringen av hva Kristus representerer. De kvalitetene Poulsen tillegger domkirken, berører dens evne til å hjelpe de troende både i det jordiske liv og i det hinsidige.

Anders Poulsen svarte tvetydig på flere spørsmål, blant annet hva slags gud han tilbad. ${ }^{117}$ Denne inkonsekvensen kan også gi grunn til å trekke i tvil hans fortolkning av andre av runebommens symboler. Som gammel noaide måtte Anders Poulsen ha inngående kunnskap om runebommens symboler og om dens bruk, både til godt og ondt. Imidlertid var det ikke denne kunnskapen han kom fram med i rettssalen. Derimot gjentok han adskillige ganger under rettssaken at han trodde på den kristne Gud og brukte runebommen kun i god hensikt. Dette samsvarer ikke med blant andre Isaac Olsens synspunkter i "Om Lappernes Vildfarelser og Overtro", der det tydelig kommer fram at en runebomme alltid ble brukt til det

onde så vel som det gode. ${ }^{118}$ Poulsens utlegning av runebommens symboler er til dels en hybrid framstillingen av kristendommens dogmer. 
Når det gjelder synspunktet at Anders Poulsens religiøse identitet og hans utlegning av runebommens symboler kunne være et resultat av samtidens brytningstid mellom førkristen religion og kristendom, understøtter ikke min analyse et slikt synspunkt. Det som kom fram i retten, var ikke et utslag av en religiøs overgangstid. Snarere var det som ble uttalt av Anders Poulsen et resultat av den konkrete og farlige situasjon han befant seg i, der det var nødvendig for ham nettopp å sette et skille mellom førkristen samisk religion og kristendommen. Hans hovedargument var jo at han hadde tatt ved kristendommen, og dette ville han overbevise rettsmyndighetene om. Derfor er det min oppfatning at den kontekst vi ser i denne saken ikke åpner for nyanser i en religiøs overgangsfase, men nettopp bidrar til at det settes et klart skille mellom den førkristne samiske religion og den kristne tro.

Påstanden om at Anders Poulsens rettssak er den beste informasjon som finnes om Noaidevuohta i Nord-Skandinavia har etter min oppfatning ikke dekning i den kilden som rettsreferatet utgjør. Poulsens forklaring kan ikke ansees som pålitelig. Han gir motstridende opplysninger på en rekke punkter og vakler når han skal gjøre rede for sitt religiøse standpunkt. Dette tyder på at kontekstuelle forhold har spilt en avgjørende rolle for den utlegningen av runebommens symboler som er nedskrevet i rettsreferatet. Ønsket om å framstå som en troende kristen og framstille sin bruk av runebommen kun i god hensikt samt uvissheten med henblikk på saken utvikling og utfall, har bidratt til den utlegning som skjer. Rettsreferatet fra trolldomssaken må settes inn i sin rettslige kontekst, og Poulsens utlegning av symbolene på runebommen må differensieres i en fortolkning. En ukritisk gjenfortelling av rettssaken, som ikke tar hensyn til de mange spenninger som ligger implisitt i teksten, vil på en uheldig måte kunne bidra til romantisering av samene.

\footnotetext{
${ }^{1}$ Jeg vil gjerne takke to anonyme reviewers for kyndige og konstruktive kommenater til artikkelnes innhold.

${ }^{2}$ Statsarkivet i Tromsø, Sorenskriveren i Finnmarks arkiv, løpenr. 25, fol. 1a.

${ }^{3}$ James R. Lewis, "New Age Medicine Men vs. New Age Noaidi: Same Neo-Shamanism, Different SocioPolitical Situation", i Siv Ellen Kraft, Trude Fonneland og James R. Lewis (red.), Nordic Neo-Shamanisms (New York, 2015), 127.

${ }^{4}$ James R. Lewis (2015), 127-128, med referanse til Carlo Castanedas forfatterskap basert på feltarbeid i Mexico, bøker publisert fra 1968 og utover, og Michael J. Harner, Jeffrey Mishlove og Arthur Bloch, The Way of the Shaman (San Fransisco, 1990, orig. utgave 1980)

${ }^{5}$ Håkan Rydving, The End of Drum-Time (Uppsala, 1993).

${ }^{6}$ Dette er også et argument innenfor forskning på ny-sjamanisme, se James R. Lewis (2015), 127-140.

${ }^{7}$ Einar Niemi, "Hans Hansen Lilienskiold - embetsmann, vitenskapsmann og opprører", i Portretter fra norsk historie (Oslo, 1993), s. 61.

${ }^{8}$ Einar Niemi, “Anders Paulsen”, i Norsk biografisk leksikon (2009). Hentet 5. januar 2016 fra https://nbl.snl.no/Anders_Paulsen.

${ }^{9}$ Rune Blix Hagen, "Harmløs dissenter eller djevelsk trollmann”, Historisk tidsskrift nr. 02-03 (2002), 326-327.

${ }^{10}$ Rune Blix Hagen, "Witchcraft and ethnicity: a critical perspective on Sami shamanism in seventeenth-century Northern Norway", i Marko Nennonen and Raisa Maria Toivo, Writing Witch-Hunt Histories. Challenging the Paradigm (Leiden, 2014), 155-163, på s. 155.
} 
${ }^{11}$ Rune Blix Hagen, "Samer er trollmenn i norsk historie" (Karasjok, 2005), s. 16. Artikkelen er gitt ut som en egen publikasjon.

${ }^{12}$ Ernst Manker, Die lappische Zaubertrommel. Eine ethnologische Monographie II (Uppsala, 1550), s. 430.

${ }^{13}$ Her kan nevnes Einar Niemi, "Anders Paulsen", i Norsk Biografisk Leksikon, b. 1 (Oslo, 1999), 84; Brita Pollan, Samiske sjamaner. Religion og utbredelse (Oslo, 1993), 32, 97; Brita Pollan, Noaidier. Historier om samiske sjamaner (Oslo, 2002), 24-31; Rune Blix Hagen, "Harmløs dissenter eller djevelsk trollmann”, Historisk tidsskrift nr. 02-03 (2002), 319-346; Rune Blix Hagen, "Sami Shamanism: The Arctic Dimension", i Magic, Rituals, and Witches, vol. 1, nr. 2 (2006), 227-233; Rune Blix Hagen, "Witchcraft and ethnicity: a critical perspective on Sami shamanism in seventeenth-century Northern Norway", i Marko Nennonen and Raisa Maria Toivo, Writing Witch-Hunt Histories. Challenging the Paradigm (Leiden, 2014), 155-163; Liv Helene Willumsen, Seventeenth-Century Witchcraft Trials in Scotland and Northern Norway (PhD thesis, University of Edinburgh, 2008), 227-245; Liv Helene Willumsen, Dømt til ild og bål (Stamsund, 2013), 336-353; Liv Helene Willumsen, Witches of the North (Leiden, 2013), 298-319

${ }^{14}$ Hans Hammonds misjonshistorie, 27-34; ’Hans Skankes Epitomes Historiæ Missions Lapponicæ Pars Qvarta, 1730", i Nordlands og Troms Finner i Eldre Håndskrifter (Oslo, 1943), 33; Isaac Olsen, "Om Lappernes Vildfarelser og Overtro", i Just Qvigstad (red.), Kildeskrifter til den lappiske mytologi II, Det Kgl. norske videnskabers selskabs skrifter 1910, no. 4 (Trondhjem, 1910); Anders Løøv, Samemisjonaren Isaac Olsen og hans "Underdanigst Undrettning om Norlandenne" (Snåsa, 1994); Edgar Reuterskiöld, Källskrifter till Lapparnas mytologi (Stockholm, 1910), 88-98, på s. 97-98; Beskrivelse over Finmarkens Lapper, deres Tungemaal, Levemaade og forrige Afgudsdyrkelse, oplyst ved mange Kaabberstykker = Canuti Leemii ... De Lapponibus Finmarchia, eorumqve lingva, vita et religione pristina commentatio, multis tabulis aeneis illustrata I med J.E. Gunneri Anmarkninger \& E.J. Jessen-S Afhandling om de Norske Finners og Lappers Hedenske Religion Kobenhavn, 1767); Jens Andreas Friis, Lappisk mythologi, eventyr og folkesagn (Kristiania, 1871); Major Peter Schnitlers Grenseeksaminajsonsprotokoller 1712-1745. Utgitt av Kjeldeskriftfondet, b. I, ved Kristian Nissen og Ingolf Kvamen; Just Qvigstad, Kildeskrifter til den lappiske mythologi, Det Kongelige Norske Vitenskapers Selskabs Skrifter (Trondheim, 1903) nr. 1 og (Trondheim, 1910) nr. 4; Martha Brock Utne og Ole Martin Solberg, Finnmark omkring 1700. Aktstykker og oversikter. Nordnorske samlinger. 1 (1938).

${ }^{15}$ Håkan Rydving, Tracing Sami traditions : in search of the indigenous religion among the Western Sami during the 17th and 18th centuries (2010), Samisk kyrkohistorisk bibliografi (2007), The End of Drum-Time (Uppsala, 1993); Rolf Kjellström og Håkan Rydving, Den samiska trumman (1988).

${ }^{16}$ Cf. note 8 ovenfor for referanser til arbeider av Niemi, Pollan, Hagen og Willumsen.

${ }^{17}$ Stein Roar Mathisen, 'Contextualizing Exhibited Versions of Sami Noaidevuohta', i Siv Ellen Kraft, Trude Fonneland og James R. Lewis (red.), Nordic Neo-Shamanism (New York, 2015), s. 191-213.

${ }^{18}$ I denne saken føres ikke vitner. Også vitnenes stemmer vil være inkludert i en analyse av rettsdokumenter der denne aksent forefinnes. Det foreligger to øyenvitneberetninger i forbindelse med fengslingen av Anders Poulsen i desember 1691, men disse nevnes ikke i rettsreferatet, og jeg går derfor ikke nøyere inn på disse. Det foregår også en rettssak etter at Anders poulsen er blitt drept, men rettsreferatet fra denne faller også utenfor denne artikkelens fokus

${ }^{19}$ Cf. Johan Tønnesson, Hva er sakprosa (Oslo, 2008), 24.

${ }^{20}$ Cf. Jürgen Macha, 'Redewiedergabe in Verhörprotokollen und der Hintergrund gesprochener Sprache', Bayerische Dialektologie. Akten der Internationalen Dialektologischen Konferenz 26.-28. Februar 2002, red. Sabine Krämer-Neubert og Norbert R. Wolf, Schriften zum Bayerischen Sprachatlas, 8 (Heidelberg, 2005), s. 171-178; Deutsche Kanzleisprache in Hexenverhörprotokollen der Frühen Neuzeit, red. Jürgen Macha, Eva Topalovic, Iris Hille, Uta Nolting og Anja Wilke, Auswahledition 1 (Berlin, 2005); Eva Topalovic, "'Ick kike in die Stern vndt versake Gott den Herrn". Versprachligung des Teufelspaktes in westfälishen Verhörsprotokollen des 16./17. Jahrhunderts', Augustin Wibbelt-Gesellschaft. Jahrbuch 20, s. 69-86. Peter Rushton, 'Texts of Authority: Witchcraft Accusations and the Demonstration of Truth in Early Modern England', Languages of Witchcraft. Narrative, Ideology and Meaning in Early Modern Culture, red. Stuart Clark (New York, 2001), s. 21-39.

${ }^{21}$ Malcolm Gaskill, 'Witches and Witnesses in New and Old England', Languages of Witchcraft, red. S. Clark, s. 55-80, på s. 56-58.

${ }^{22}$ Slike muntlighetstrekk er additive setningsstrukturer, aggregerende språkelementer, overflødighet av ord, nærhet til den menneskelige verden samt en fiendtlig tone. Ref. Walter J. Ong, Orality and Literacy, pp. 37-45. Barbara Kryk-Kastovsky har i en studie av tidlig moderne engelske rettsdokumenter funnet at rettsreferater beholder mange muntlighetstrekk. Studien er basert på to termer:" turn-taking” og "closeness to the sociocultural context". Ref. Barbara Kryk-Kastovsky, 'Representations of Orality in Early Modern English Trial Records', Journal of Historical Pragmatics, 1(2), (2000): 201-230, på s. 209. Ref. Barbara Kryk-Kastovsky, 'Historical courtroom discourse', Journal of Historical Pragmatics, 7 (2) (2006): 213-45; Barbara KrykKastovsky, 'How bad is "bad data"? In search for the features of orality in Early Modern English legal texts', 
Current Issues in Unity and Diversity of Languages. Collection of papers selected from the CIL 18, held at Korea University in Seoul on July 21-26, 2008. Seoul; The linguistic society of Korea; Kathleen L. Doty, 'Telling tales. The Role of Scribes in Constructing the Discourse of the Salem Witchcraft Trials', Journal of Historical Pragmatics, 8 (1) (2007): 25-41, på s. 26, 27, 39.

${ }^{23}$ Elizabeth S. Cohen, 'Back Talk: Two Prostitutes' Voices from Rome c. 1600', Early Modern Women: An Interdisciplinary Journal, 2 (2007); Elizabeth S. Cohen, 'Between Oral and Written Culture: The Social Meaning of an Illustrated Love Letter', Culture and Identity in Early Modern Europe (1500-1800): Essays in Honour of Natalie Zemon Davis, red. Barbara B. Diefendorf og Carla Hesse (Michigan, 1993), s. 181-201, på s. 95, 96.

${ }^{24}$ Se Raisa Maria Toivo, Witchcraft and Gender in Early Modern Society. Se også Per-Anders Östling, 'Blåkulla Journeys in Swedish Folklore',Arv: Nordic Yearbook of Folklore, 62 (2006), 81-122; Marie Lennersand, 'Rättvik', 375-596, i Marie Lennersand og Linda Oja, Livet går vidare; Marie Lennersand og Linda Oja, 'Vitnande visionärer. Guds och Djävulens redskap i Dalarnas häxprocesser', 177-184, i Hanne Sanders (red.), Mellom Gud og Djaevelen. Religiфse og magiske verdensbilleder i Norden 1500 -1800 (København, 2001); Jari Eilola, 'Lapsitodistajien kertomukset Ruotsin noitatapaukissa 1668-1676' [Barnevitner i trolldomssaker i Sverige 1668-1676], E-journal Kasvatus and Aika, 3 (2009, upaginert); Liv H. Willumsen, 'Children Accused of Witchcraft in $17^{\text {th }}$-century Finnmark', Scandinavian Journal of History, vol. 38, no. 1 (2013), 18-41.

${ }^{25}$ Liv Helene Willumsen, "Oral transference of ideas about witchcraft in seventeenth-century Norway", $\mathrm{i}$ Thomas Cohen and Leslie Twomey (eds.), Spoken Word and Social Practice (Brill, Leiden, 2015, kommer); Liv Helene Willumsen, Witches of the North (Leiden, 2013); Liv Helene Willumsen, Dømt til ild og bål (Stamsund, 2013); Liv Helene Willumsen, Seventeenth-Century Witchcraft Trials in Scotland and Northern Norway (PhD thesis, University of Edinburgh, 2008).

${ }^{26}$ Statsarkivet i Troms $\varnothing$, Sorenskriveren i Finnmarks Arkiv (SAT, , SF), 1øpenr. 25, fol. $2 \mathrm{a}$.

${ }^{27}$ SATØ, SF 25, fol. 2b.

${ }^{28}$ SATØ, SF 25, fol. 2b.

${ }^{29}$ SATØ, SF 25, fol. 2b.

${ }^{30}$ SATØ, SF 25, fol. 2b.

${ }^{31}$ SATØ, SF 25, fol. 2a-2b.

32 SAT, , SF 25, fol. 2b.

33 SATØ, SF 25, fol. 2b.

${ }^{34}$ SAT $\varnothing$, SF 25, fol. 2b.

${ }^{35}$ SAT $\varnothing$, SF 25, fol. 3a.

${ }^{36}$ SATØ, SF 25, fol. 3a.

${ }^{37}$ SAT Ø, SF 25, fol. 3a.

${ }^{38}$ SAT $\varnothing$, SF 25, fol. 3a.

${ }^{39}$ SAT $\varnothing$, SF 25, fol. 3a.

${ }^{40}$ SATØ, SF 25, fol. 2a.

${ }^{41}$ SATØ, SF 25, fol. 3a.

${ }^{42}$ SATØ, SF 25, fol. 3a-3b.

${ }^{43}$ SAT $\varnothing$, SF 25, fol. 3b.

${ }^{44}$ SATØ, SF 25, fol. 3b.

${ }^{45}$ SATØ, SF 25, fol. 3b.

${ }^{46}$ SATØ, SF 25, fol. 3b-4a.

${ }^{47}$ SAT $\varnothing$, SF 25, fol. 4a.

${ }^{48}$ SATØ, SF 25, fol. 4a.

${ }^{49}$ SAT $\varnothing$, SF 25, fol. 4a.

${ }^{50}$ SAT Ø, SF 25, fol. 4a.

${ }^{51}$ SATØ, SF 25, fol. 4a.

52 SATØ, SF 25, fol. 4a.

${ }^{53}$ SATØ, SF 25, fol. 4b.

${ }^{54}$ SATØ, SF 25, fol. 4b.

55 SATØ, SF 25, fol. 4a.

${ }^{56}$ SAT $\varnothing$, SF 25, fol. 4b.

57 SAT Ø, SF 25, fol. 4b.

${ }^{58}$ SATØ, SF 25, fol. 4b.

${ }^{59}$ SATØ, SF 25, fol. 5 a.

${ }^{60}$ SATØ, SF 25, fol. 5a.

${ }^{61}$ I denne sammenhengen betyr ordet finsk.

${ }^{62}$ SATØ, SF 25, fol. 5 a. 
${ }^{63}$ SAT $\varnothing$, SF 25, fol. 5a.

${ }^{64}$ SATØ, SF 25, fol. 5 a.

${ }^{65}$ SAT, , SF 25 , fol. 5 b.

${ }^{66}$ SATØ, SF 25, fol. 5 b.

${ }^{67}$ SAT $\varnothing$, SF 25, fol. 6 a.

${ }^{68}$ SAT $\varnothing$, SF 25, fol. 6 a.

${ }^{69}$ SAT Ø, SF 25, fol. 6 a.

${ }^{70}$ SATØ, SF 25, fol. 6a-6b.

${ }^{71}$ SATØ, SF 25, fol. 7b.

${ }^{72}$ SAT $\varnothing$, SF 25, fol. 8a.

${ }^{73}$ SAT Ø, SF 25, fol. 8a.

${ }^{74}$ SATØ, SF 25, fol. 8a.

${ }^{75}$ SAT $\varnothing$, SF 25, fol. 8a.

${ }^{76}$ SATØ, SF 25, fol. 8b.

${ }^{77}$ SATØ, SF 25, fol. 11b.

${ }^{78}$ SATØ, SF 25, fol. 15a.

${ }^{79}$ Pollan, Samiske beretninger, 24.

${ }^{80}$ SATØ, SF 25, fol. 3 a.

${ }^{81}$ Fra en samtidig kilde skrevet av Niels Knag datert 15. desember 1693 kommer det fram at Anders Poulsen var beveget og felte tårer i rettssalen. Ref. Appendix til Thott nr. 1735, Kongelige Bibliotek, København.

${ }^{82}$ Niemi, E., "Hans Hansen Lilienskiold - embetsmann, vitenskapsmann og opprører", i Portretter fra norsk historie ( Oslo 1993), 61; Niemi, "Anders Paulsen (Poulsen, Pouelsen)", 84; Rydving, H., The End of drum-time: Religious Change among the Lule Saami, 1670s-1740s (Uppsala, 1995), 35-42; Hagen, "Samisk", 2.

${ }^{83}$ SATØ, SF 25, fol. 1a-1b.

${ }^{84}$ SATØ, SF 25, fol. 7b.

${ }^{85}$ SATØ, SF 25, fol. 2a.

${ }^{86}$ SATØ, SF 25, fol. 2a.

${ }^{87}$ SATØ, SF 25, fol. 3a.

${ }^{88}$ SATØ, SF 25, fol. 3 b.

${ }^{89}$ SATØ, SF 25, fol. 3b.

${ }^{90}$ SATØ, SF 25, fol. 3b.

${ }^{91}$ SATØ, SF 25, fol. 5a.

${ }^{92}$ SAT, SF 25 , fol. $5 \mathrm{~b}$.

${ }^{93}$ SATØ, SF 25, fol. 6b.

${ }^{94}$ SATØ, SF 25 , fol. 6 b.

${ }^{95}$ SATØ, SF 25, fol. $7 \mathrm{~b}$.

${ }^{96}$ SATØ, SF 25, fol. 7b.

${ }^{97}$ SAT $\varnothing$, SF 25, fol. 8 a.

${ }^{98}$ SATØ, SF 25, fol. 8a.

${ }^{99}$ SATØ, SF 25, fol. 8a.

${ }^{100}$ Lov vedtatt i 1686 bestemte at en dødsdom avsagt i en trolldomssak skulle forelegges kongen før henrettelse.

${ }^{101}$ SATØ, SF 25, fol. 5a.

${ }^{102}$ Håkan Rydving, Samisk Religionshistorisk bibliografi (Uppsala, 1993); J. Qvigstad og K. B. Wicklund, Bibliographie der Lappischen Literatur (Helsingfors, 1899); Berättelser om samerna i 1600-talets Sverige (Kungl. Skytteanska Samfundets handlingar (Nr. 27, 1983) gir en del opplysninger om trommer og samisk gudstjeneste; Håkan Rydving, The End of Drum-Time (Uppsala, 1993), særlig kapitlene 'Ritual Aspects' og 'Social Aspects' redegjør for vesentlige aspekter ved samisk sjamanisme. Samiske guder og gudinner er også omskrevet i Hans Mebius' bok Bissie: studier i samisk religionshistorie.

${ }^{103}$ Lars Nilsson brukte runebomme og trefigurer. Han ble dømt til bålet, og både trommen og trefigurene ble brent før ham selv. Ref. Granquist, K., "Du skal inga andra gudar hava jämte mig", i B-P. Finstad (red.), Stat, religion, etnisitet (Tromsø, 1997), 71-88.

${ }^{104}$ Han ble dømt til døden av lokal rett, men på veien til henrettelsesstedet falt han død om, angivelig grunnet trolldom. Ref. Fellman, I., Handlingar och uppsatsar angåande finska lappmarken och lapparne, vol. I (Helsingfors, 1910), 383-86.

${ }^{105}$ Jørkov, B., "Den stærke tromme", Siden Saxo, nr. 1 (2000), 9-17.

${ }^{106}$ Se arbeider av K. Leem 1767, J.A. Friis 1871, J. Qvigstad 1903, S. Agrell 1934, T. I. Itkonen 1956, E. Manker 1950 og L. Bäckman 1975. Ref. Leem, K., Beskrivelse over Finmarkens Lapper (København, 1767); Friis, J. A., Lappisk mytologi. Eventyr og Folkesagn (Christiania, 1871); Qvigstad, J., Kildeskrifter til den lappiske mytologi (Trondheim, 1903); Agrell, S., Lapptrummor och runmagi (Lund, 1934); Itkonen, T. I., 
Heidnischer Religion und Späterer Aberglaube bei den Finnishen Lappen (Helsinki, 1956); Manker, Die lappische; Bäckman, L., Sájva: föreställinger om hjälp- och skyddsväsen $i$ helige fjäll bland samerna (Stockholm, 1975); Ernst Manker, Nåjdkonst. Trolltrummans bildvärld ((Halmstad, 1965).

${ }^{107}$ Blant annet har man Niels Knags beskrivelse, publisert i Nordnorske Samlinger. Fra 1711 "Instruks for helligdagsvægterne" (prestens medhjelpere) utstedt av amtmann Lorch og prost Paus, ref. "Hans Skankes Epitomes Historiæ Missions Lapponicæ Pars Qvarta, 1730", i Nordlands og Troms Finner i Eldre Håndskrifter (Oslo, 1943), 33. I tillegg inneholder prost Paus' relasjon av 1715, vesentlig bygget på Isaac Olsens meddelelser, opplysninger om "Lappernes hedenskap". Isaac Olsen skrev i 1717, etter at hadde forlatt Finnmark, "Om Lappernes Vildfarelser og Overtro", ref. Just Qvigstad (red.), Kildeskrifter til den lappiske mytologi II, Det Kgl. norske videnskabers selskabs skrifter 1910, no. 4 (Trondhjem, 1910). Se også Hammonds misjonshistorie, 27-34. ${ }^{108}$ Utgitt av Kjeldeskriftfondet, b. I, ved Kristian Nissen og Ingolf Kvamen.

${ }^{109}$ Edgar Reuterskiöld, Källskrifter till Lapparnas mytologi (Stockholm, 1910), 88-98, på s. 97-98.

${ }^{110}$ Edgar Reuterskiöld, Källskrifter till Lapparnas mytologi (Stockholm, 1910), 1-7, på s. 2.

${ }^{111}$ Troms $\varnothing$ Museums skrifter XXIV, Nordkalott-forlasget (1993).

${ }^{112}$ Rolf Kjellström og Håkan Rydving, Den samiska trumman (Nordiska Museet, 1988); Edgar Reuterskiöld, Källskrifter till Lapparnas mytologi (Stockholm, 1910), 28-41, på s. 31-36.

${ }^{113}$ Isaac Olsen, "Om Lappernes Vildfarelser og Overtro", i Just Qvigstad (red.), Kildeskrifter til den lappiske mytologi II, Det Kgl. norske videnskabers selskabs skrifter 1910, no. 4 (Trondhjem, 1910), 22; K.B. Wicklund (red.), Berättelser om Samerna i 1600-talets Sverige (1983), 67.

${ }^{114}$ Edgar Reuterskiöld, Källskrifter till Lapparnas mytologi (Stockholm, 1910), 88-98, på s. 94-96;Brita Pollan, Noaidier. Historier om samisk sjamaner (Oslo, 2002), XXII.

${ }_{115}^{115}$ Pollan, Samiske beretninger, 24.

${ }^{116}$ SATØ, SF 25, fol. $3 \mathrm{a}$.

${ }^{117}$ SATØ, SF 25, fol. 3a.

${ }^{118}$ Isaac Olsen, "Om Lappernes Vildfarelser og Overtro", i Just Qvigstad (red.), Kildeskrifter til den lappiske mytologi II, Det Kgl. norske videnskabers selskabs skrifter 1910, no. 4 (Trondhjem, 1910), 40. 